\author{
JOEL W.I. MILLAR†
}

\title{
INTRODUCTION
}

If a wayward rancher steals his neighbor's cow, he should be punished. If the rancher steals his neighbor's cow again, he should be punished more severely. This, at least, is the normative judgment reflected in the various recidivist statutes codified in state and federal criminal law. Recidivist statutes permit and often require stiffer penalties for criminal defendants who have previously been convicted of one or more crimes. ${ }^{1}$

Not all prior convictions, however, render a convicted defendant eligible for stiffer punishment. In United States $v$. Tucker, ${ }^{2}$ the United States Supreme Court held that the Sixth Amendment prohibits the use of a prior conviction to enhance a criminal defendant's sentence if that conviction was obtained in violation of the right to counsel. ${ }^{3}$ The Supreme Court has defined the right to counsel as the right to be represented by a lawyer in criminal prosecutions. For indigent defendants (those who cannot afford to hire a private lawyer), this is the right to be represented by a courtappointed lawyer. Unless an indigent defendant waives this right, the state must provide the defendant with a lawyer. If the state does not provide a lawyer, any resulting conviction is unconstitutional and can be reversed. ${ }^{4}$

The right to court-appointed counsel, however, does not extend to all criminal prosecutions. The Supreme Court has limited this right to felony convictions and to those misdemeanor convictions

† B.A. 1993, University of Florida; J.D. Candidate 1996, University of Pennsylvania. I thank Professor Rudovsky for his suggestions on an earlier draft, and I thank the members of the Law Review for their careful editing. I especially thank Michael Baughman, Erica Dao, and Hilary Siegel for their invaluable assistance and patience. Finally, I thank my parents for their constant support in all that I do.

${ }^{1}$ See infra notes 13-24 and accompanying text.

2404 U.S. 443 (1972).

${ }^{3}$ See id. at 449.

${ }^{4}$ See infra notes 37-52 and accompanying text. 
that give rise to a jail sentence. ${ }^{5}$ In Scott $v$. Illinois, ${ }^{6}$ the Court held that if the defendant is convicted of a misdemeanor and is not sentenced to any time in jail, but rather is ordered to pay a criminal fine or to serve a probationary sentence, the Sixth Amendment does not require the state to provide the defendant with a lawyer. ${ }^{7}$ In this limited class of prosecutions, an indigent defendant may be validly convicted under the Constitution, even though the defendant did not have a lawyer.

Can these valid but uncounseled misdemeanor convictions be used to enhance a defendant's sentence? In its most recent right to counsel decision, Nichols $v$. United States, ${ }^{8}$ the Supreme Court held that they can. ${ }^{9}$ The Court explained that enhancing a defendant's sentence on the basis of a valid uncounseled conviction punishes only the last offense, not the uncounseled conviction, and thus does not violate the Sixth Amendment under Scott because no imprisonment has been imposed for the uncounseled conviction. ${ }^{10}$ Furthermore, the Court distinguished Tucker by pointing out that a valid but uncounseled misdemeanor conviction does not violate the right to counsel. ${ }^{11}$ Finally, the Court explained that the consideration of a defendant's prior uncounseled convictions under a recidivist statute satisfies the relaxed requirements of due process in the sentencing stage of a criminal prosecution. ${ }^{12}$

This Comment examines the reasons offered by the Court in Nichols and concludes that the Court failed to provide a valid rationale for its decision. Part I discusses the mechanics, theory, and constitutionality of recidivist statutes. Part II describes the evolution of the right to counsel and of the Sixth Amendment limitation on the collateral use of prior convictions. Part III summarizes the majority, concurring, and dissenting opinions in Nichols. Part IV considers each of the Court's justifications for its Nichols decision. Part IV concludes that, first, the Court cannot rely on Scott to uphold enhancement because, by the Court's own reasoning, Scott does not apply. Second, the Court cannot distinguish Tucker by relying on the constitutional validity of an

\footnotetext{
${ }^{5}$ See infra notes 38-59 and accompanying text.

${ }^{6} 440$ U.S. 367 (1979).

7 See id. at 373-74 (citing Argersinger v. Hamlin, 407 U.S. 25 (1972)).

8114 S. Ct. 1921 (1994).

${ }^{9}$ See id. at 1928.

${ }^{10}$ See infra notes $143-45$ and accompanying text.

II See infra notes 150-52 and accompanying text.

${ }^{12}$ See infra notes $119-23$ and accompanying text.
} 
uncounseled misdemeanor conviction because the decision in Tucker was motivated by the lack of counsel rather than the formal constitutional validity or invalidity of the prior conviction. Finally, because the issue must stand or fall with the Sixth Amendment, the Court's due process argument is irrelevant. Part V examines Justice Souter's approach and concludes that it also is difficult to square with the Court's Sixth Amendment jurisprudence. Part V suggests a resolution more consistent with the principles underlying the Court's right to counsel cases. Finally, Part VI urges state courts and legislatures to look beyond Nichols in deciding whether to permit the collateral use of valid uncounseled convictions.

\section{RECIDIVIST STATUTES}

Sentence-enhancement (or recidivist) statutes generally require that courts impose heavier penalties upon offenders who have previously been convicted of a criminal offense than upon those who have not. The form that recidivist statutes take varies from state to state, with some increasing the applicable sentencing range ${ }^{13}$ or upgrading the offense classification, ${ }^{14}$ and with others mandating a particular disposition, such as the maximum penalty authorized by the conviction offense, ${ }^{15}$ a specified period of

${ }^{13}$ See, e.g., U.S. SENTENCING CoMm'N, Guidelines MANUAL §§ 4A1.1-.3 (1993) (increasing the applicable sentencing range by placing the defendant in one of six criminal history categories determined by the cumulative criminal history points attributed to the defendant's prior convictions, and authorizing upward departures for unconvicted criminal behavior if established by reliable information and necessary to reflect the seriousness of the defendant's past criminal behavior or likelihood of committing future crimes); CAL. PENAL CODE $\$ 667(e)(1)$ (West Supp. 1995) (requiring a court to sentence a defendant with one prior felony conviction to twice the term of incarceration otherwise provided as punishment for the conviction offense); FLA. STAT. ANN. \$ 775.084(4)(a)(2)-(3) (West Supp. 1995) (increasing the maximum penalty for defendants convicted of second- or third-degree felonies who have two prior felony convictions to twice the term of imprisonment normally applicable to second- and third-degree felonies under FLA. STAT. ANN. $\$ 775.082(3)(c)$-(d) (West 1992)); Mich. CoMP. LAws ANN. $\$ 769.10(1)(a)$ (West 1982) (increasing the sentencing range for defendants with a prior felony conviction to one and one-half times the maximum sentence specified for the conviction offense); N.J. STAT. ANN. § 2C:43-7(a) (West 1995) (requiring courts to apply an increased sentencing range to the conviction offense for defendants with two prior convictions for specified serious crimes, and permitting courts to apply the increased sentencing range to the conviction offense for defendants with any two prior convictions).

i4 See, e.g., ALA. CODE § 13A-5-9(a) to (c) (1994) (upgrading a felony conviction by one letter for each prior felony conviction, with mandatory life for class $A$ or class $B$ felony convictions and minimum 15 years to life for class $\mathbf{C}$ felony convictions upon conviction of a defendant's fourth felony).

${ }^{15}$ See, e.g., GA. CODE ANN. § 17-10-7(a) (Supp. 1995) (requiring courts to impose 
incarceration (either as a minimum sentence $e^{16}$ or in addition to the base sentence ${ }^{17}$ ), or, in the extreme, life imprisonment. ${ }^{18}$ Recidivist statutes also vary in the kind of prior convictions that will trigger enhanced punishment. Some statutes only apply to serious felonies, ${ }^{19}$ others to a range of specified felony and misdemeanor offenses, ${ }^{20}$ and yet others to virtually all criminal offenses. ${ }^{21}$ Whatever their form or scope, however, all recidivist statutes share the same goal: punishing repeat offenders more severely than firsttime offenders.

the maximum sentence authorized for the conviction offense if the defendant has served a prison term for a prior felony conviction).

${ }^{16}$ See, e.g., TEX. PENAL CODE ANN. \$ 12.43(a)-(b) (West 1994) (requiring a mandatory minimum sentence of 90 days in jail for the second commission of a class A misdemeanor and 30 days in jail for the second commission of a class $B$ misdemeanor).

${ }^{17}$ See, e.g., CAL. PENAL CODE $\$ 667(a)$ (1) (requiring the addition of a five-year period of incarceration to the base sentence for each prior conviction of a serious felony).

${ }^{18}$ See, e.g., CaL. Penal Code $\S 667(\mathrm{e})(2)(\mathrm{A})$ (requiring an indeterminate sentence of life imprisonment upon a defendant's third felony conviction); FLA. STAT. ANN. $\S 775.084(4)(a)(1)$ (requiring a sentence of life imprisonment for a first-degree felony if the defendant has been previously convicted of two felonies); ILL. COMP. STAT. ANN. ch. 720, § 5/33B-1(e) (Smith-Hurd Supp. 1995) (requiring a sentence of life imprisonment upon the third conviction of a class $\mathrm{X}$ felony, criminal sexual assault, aggravated kidnapping, or first-degree murder); N.J. STAT. ANN. § 2C:43-7.1 (West 1995) (providing for "life imprisonment . . . with no eligibility for parole" for an individual convicted of murder, aggravated manslaughter, first-degree kidnapping, sexual assault, robbery, or carjacking if the individual has been convicted twice before for any of the foregoing or substantially equivalent offenses).

${ }^{19}$ See, e.g., CAL. PENAL CODE $§ 667$ (a)-(b), (e) (providing for enhancement of only felony convictions, and stating that ${ }^{~}[\mathrm{i}] \mathrm{t}$ is the intent of the Legislature . . . to ensure longer prison sentences and greater punishment for those who commit a felony and have been previously convicted of serious and/or violent felony offenses"); FLA. STAT. ANN. § 775.084(4)(a) (providing for enhancement of only felony convictions); MICH. COMP. LAWS ANN. $\$ 769.10$ (same).

${ }^{20}$ See, e.g., GUIDELINES MANUAL § 4A1.2(c) (providing for enhancement of all felonies and all misdemeanors except for those misdemeanors specified in one of two lists, the first list specifying offenses that will not be subject to enhanced penalties if the conviction offense is not similar and if the defendant did not receive a 30-day jail sentence or one-year sentence of probation for the conviction of the specified misdemeanor, and the second list specifying offenses that may never be the subject of enhancement, such as minor traffic infractions or vagrancy).

${ }^{21}$ See, e.g., D.C. CODE ANN. \$ 22-104 (Supp. 1995) (increasing the penalty of any criminal offense, other than a nonmoving traffic offense, by time and a half if the defendant has been previously convicted of a similar offense, and by three times if the defendant has been twice before convicted of a similar offense); N.J. STAT. ANN. § 2C:43-7 (permitting a court to enhance the sentence of the conviction offense if the defendant has been convicted of two prior crimes). 
Enhanced punishment for repeat offenders is generally justified on the grounds of retribution, general deterrence, and specific deterrence. First, criminals are considered more culpable when they commit crimes after having been convicted and punished for a previous crime. ${ }^{22}$ Second, aggravated punishment for repeated criminal behavior is thought to be necessary to deter future crimethose considering committing a second or third criminal act will think twice if they know they will go to jail for an extended period of time. ${ }^{23}$ Finally, enhanced punishment is justified because repeat offenders have not been deterred by lesser sanctions and because their demonstrated propensity to commit crime poses a danger to society. ${ }^{24}$

Sentence-enhancement statutes have been upheld by the Supreme Court against a variety of constitutional challenges, including double jeopardy, ${ }^{25}$ due process, ${ }^{26}$ equal protection, ${ }^{27}$

${ }^{22}$ See Guidelines MANUAL ch. 4, pt. A introductory cmt. (stating that a defendant with a prior criminal record is more culpable than a first offender and thus deserving of greater punishment); Spencer v. Texas, 385 U.S. 554, 571 (1967) (Warren, C.J., dissenting in part and concurring in part) (stating that prior crimes are thought to aggravate guilt for subsequent crimes, thereby warranting greater retribution); Alex Glashausser, The Treatment of Foreign Country Convictions As Predicates for Sentence Enhancement Under Recidivist Statutes, 44 DUKE L.J. 134, 154 (1994) (stating that state courts, finding commission of subsequent crimes in and of themselves worse than a first offense, most often cite retribution as the justification underlying recidivist statutes).

${ }^{23}$ See Guidelines Manual ch. 4, pt. A introductory cmt. ( ${ }^{\circ}$ General deterrence of criminal conduct dictates that a clear message be sent to society that repeated criminal behavior will aggravate the need for punishment with each recurrence."); Spencer, 385 U.S. at 571 (stating that one of the aims of recidivist statutes is to deter future crime); Glashausser, supra note 22, at 154 (noting that deterrence is one of the traditional rationales underlying recidivist statutes).

${ }^{24}$ See Guidelines MANUaL ch. 4, pt. A introductory cmt. (stating that past criminal conduct is important to assess the likelihood of future criminal conduct); Spencer, 385 U.S. at $\mathbf{5 7 1}$ (stating that recidivist statutes aim to protect society from dangerous persons whose criminal propensities are demonstrated by repeated criminal behavior). The Federal Sentencing Guidelines also note that repeated criminal behavior indicates a limited likelihood of successful rehabilitation. See GUIDELINES MANUAL ch. 4, pt. A introductory cmt.

${ }^{25}$ See Graham v. West Virginia, 224 U.S. 616, 623 (1912) ("The propriety of inflicting severer punishment upon old offenders has long been recognized in this country .... They are not punished the second time for the earlier offense, but the repetition of criminal conduct aggravates their guilt and justifies heavier penalties when they are again convicted."); McDonald v. Massachusetts, 180 U.S. 311, 313 (1901) (holding that recidivist statutes do not violate principles of double jeopardy); Moore v. Missouri, 159 U.S. 673, 677 (1895) (holding that recidivist statutes do not violate principles of double jeopardy because the increased penalty punishes the last offence committed, rather than the first).

${ }^{26}$ See Graham, 224 U.S. at 625 (holding that a state recidivist statute providing for 
ex post facto laws, ${ }^{28}$ privileges and immunities, ${ }^{29}$ and cruel and unusual punishment claims. ${ }^{30}$ As the Court in Nichols v. United States $^{31}$ noted, recidivist statutes have been regarded as punishing the last offense only, ${ }^{32}$ and the Court has recognized the states' legitimate interest in deterring habitual criminals by singling them out for additional punishment through recidivist statutes. ${ }^{33}$

This Comment focuses on one particular constitutional problem concerning recidivist statutes-the extent to which a defendant's Sixth Amendment right to counsel is implicated when a prior uncounseled conviction is used to send a defendant to jail for a significantly greater period of time. This was the issue the Supreme

a separate enhancement proceeding does not violate the Due Process Clause).

${ }_{27}$ See Moore, 159 U.S. at 678 (holding that recidivist statutes do not violate the Equal Protection Clause as long as all repeat offenders are treated more severely than first offenders for committing the same offense).

${ }^{28}$ See Gryger v. Burke, 334 U.S. 728, 732 (1948) (rejecting the argument that applying a recidivist statute to a conviction obtained before the statute was enacted violated the Ex Post Facto Clause); McDonald, 180 U.S. at 312 ("The fundamental mistake of the plaintiff in error is his assumption that the judgment below imposes an additional punishment on crimes for which he had already been convicted and punished .... The statute, imposing a punishment on none but future crimes, is not ex post facto.").

${ }^{29}$ See Graham, 224 U.S. at 631 (holding that a state recidivist statute that provides for a separate sentence-enhancement proceeding does not violate the Privileges and Immunities Clause of the Fourteenth Amendment).

${ }^{30}$ See McDonald, 180 U.S. at 313 (holding that recidivist statutes do not impose cruel or unusual punishment); Moore, 159 U.S. at 677 ( ${ }^{\text {} I t ~ i s ~ q u i t e ~ i m p o s s i b l e ~ f o r ~ u s ~}$ to conclude that the supreme court of Missouri erred in holding that . . . the increase of his punishment by reason of the commission of the first offence was not cruel and unusual.").

31114 S. Ct. 1921 (1994).

${ }^{32}$ See infra note 118 and accompanying text; see also Parke v. Raley, 113 S. Ct. 517, 522 (1992) (noting that a charge under a recidivism statute does not state a separate offense, but affects punishment only); Gryger, 334 U.S. at 732 ("The sentence as a fourth offender or habitual criminal is not to be viewed as either a new jeopardy or additional penalty for the earlier crimes. It is a stiffened penalty for the latest crime, which is considered to be an aggravated offense because a repetitive one."); Graham, 224 U.S. at 623 ("[Recidivists] are not punished the second time for the earlier offense, but the repetition of criminal conduct aggravates their guilt and justifies heavier penalties when they are again convicted."); Moore, 159 U.S. at 677 (stating that under recidivist statutes "the punishment is for the last offence committed, and it is rendered more severe in consequence of the situation into which the party had previously brought himself" (quoting Ross's Case, 2 Pick. 165)).

${ }^{33}$ See Parke, 113 S. Ct. at 522 (citing Rummel v. Estelle, 445 U.S. 263, 284 (1980)); Spencer v. Texas, 385 U.S. 554, 563 (1967); see also id. at 566 ("Tolerance for a spectrum of state procedures dealing with a common problem of law enforcement is especially appropriate here. The rate of recidivism is acknowledged to be high, a wide variety of methods dealing with the problem exists, and experimentation is in progress."). 
Court addressed in Nichols. Before turning to the Nichols case, however, it will be useful to review the Supreme Court's Sixth Amendment jurisprudence.

\section{THE SIXTH AMENDMENT'S RIGHT TO COUNSEL JURISPRUDENCE: RELIABILITY, CONSEQUENCES, AND STATE BURDENS}

The Sixth Amendment of the United States Constitution guarantees that "[i]n all criminal prosecutions, the accused shall enjoy the right ... to have the Assistance of Counsel for his defence." ${ }^{34}$ Although originally understood to apply to the federal courts only, ${ }^{35}$ the right to counsel now applies to the same extent in criminal proceedings prosecuted in the state courts. $^{36}$ The Sixth Amendment requires both state and federal courts to affirmatively appoint counsel to represent both indigent defendants charged with felonies and indigent defendants charged with misdemeanors that result in a sentence of imprisonment upon conviction, unless the defendant "intelligently and competently" waives the right. ${ }^{37}$

By its terms, the Sixth Amendment applies to all criminal prosecutions. The Court, however, has stopped short of extending

34 U.S. CONST. amend. VI.

${ }^{35}$ See Barron v. Mayor of Baltimore, 32 U.S. (7 Pet.) 243, 247 (1833) (holding that the Bill of Rights only restrains the federal government, not the state governments).

${ }^{36}$ See Gideon v. Wainwright, 372 U.S. 335, 342-44 (1963) (holding that the Sixth Amendment is applicable to the states through the Fourteenth Amendment's Due Process Clause). The federal appellate courts have held the right to counsel in federal court under the Sixth Amendment to be co-extensive with the right to counsel in state court under the Fourteenth Amendment. See United States v. Quemado, 26 F.3d 920, 923 (9th Cir. 1994) (holding that a defendant in a federal prosecution had no right to counsel under Scott v. Illinois, 440 U.S. 367 (1979), because no imprisonment was imposed); United States v. Doe, 743 F.2d 1033, 1038 (4th Cir. 1984) (stating that Scott governs the right to counsel in federal court for federal offenses). Both Quemado and Doe refused to recognize a broader right to counsel in federal court than the standards prescribed for state courts in Scott.

${ }^{37}$ See Nichols v. United States, 114 S. Ct. 1921, 1925 n.9 (1994); Scott, 440 U.S. at 374 (holding that the right to assistance of appointed counsel must be provided to any indigent defendant who receives a sentence of imprisonment); Argersinger $v$. Hamlin, 407 U.S. 25, 37 (1972) (same); Burgett v. Texas, 389 U.S. 109, 114 (1967) (stating that the prosecution of a defendant for a felony offense would be unconstitutional unless the defendant had a lawyer or had validly waived the right to one); Gideon, 372 U.S. at 344-45 (holding a felony conviction unconstitutional because it was obtained without the assistance of counsel); Powell v. Alabama, 287 U.S. 45, 71 (1932) (holding that due process and the Sixth Amendment require affirmative assignment of counsel to indigent defendants when they are unable to make an adequate defense in capital cases). 
the right to court-appointed counsel to all criminal prosecutions, drawing the line at actual imprisonment in misdemeanor cases. ${ }^{38}$ Why? What are the underlying Sixth Amendment principles that have led to this result?

This Part opens with an examination of those underlying principles that have guided the Court in developing its interpretation of the Sixth Amendment. This Part then proceeds to analyze the Sixth Amendment constraints on the collateral use of uncounseled convictions.

\section{A. The Right to Counsel}

1. Reliability: The Need for Defense Counsel in Criminal Prosecutions

At the core of the Sixth Amendment's right to counsel is the proposition that the assistance of counsel is essential to a fair trial. Gideon $v$. Wainwright ${ }^{39}$ represents the Court's most dramatic statement of this principle, holding that the right to counsel belongs among the fundamental rights embraced by the Fourteenth Amendment's Due Process Clause. ${ }^{40}$ The development of this doctrine, however, dates back at least another thirty years before the Gideon decision to Powell v. Alabama. ${ }^{41}$

It was in Powell, a case in which the defendants were under a sentence of death, ${ }^{42}$ that the Court first articulated the need for defense counsel in criminal prosecutions to guarantee reliability. The Powell Court emphasized the defendants' need for counsel not only at trial, but also in preparation for trial. Thus, appointment of counsel on the morning of trial was rejected as inadequate because it was the period between arraignment and trial, "when consultation, thoroughgoing investigation and preparation were vitally important, ${ }^{\text {"33 }}$ that the aid of counsel was perhaps most critical to the criminal defendant.

The Court also underscored the importance of counsel during the trial itself by noting that the right to be heard is "of little avail

\footnotetext{
${ }^{38}$ See infra notes $61-74$ (discussing the Scott decision).

${ }^{99} 372$ U.S. 335 (1963).

${ }^{40}$ See id. at 342-43.

1287 U.S. 45 (1932).

42 See id. at 50.

${ }^{43} \mathrm{Id}$. at 57.
} 
if it [does] not comprehend the right to be heard by counsel." ${ }^{34}$ Without knowledge of the evidentiary and procedural rules governing trials and the substantive criminal law governing the prosecution's charge, the defendant would rarely be able to challenge the prosecution's case with any real effectiveness, regardless of the merits of his defense. As the Court explained:

Even the intelligent and educated layman has small and sometimes no skill in the science of law. If charged with crime, he is incapable, generally, of determining for himself whether the indictment is good or bad. He is unfamiliar with the rules of evidence. Left without the aid of counsel he may be put on trial without a proper charge, and convicted upon incompetent evidence, or evidence irrelevant to the issue or otherwise inadmissible. He lacks both the skill and knowledge adequately to prepare his defense, even though he have a perfect one. He requires the guiding hand of counsel at every step in the proceedings against him. Without it, though he be not guilty, he faces the danger of conviction because he does not know how to establish his innocence. If that be true of men of intelligence, how much more true is it of the ignorant and illiterate, or those of feeble intellect. ${ }^{45}$

With these considerations in mind, the Powell Court determined that in a capital case "the necessity of counsel [is] so vital and imperative that the failure of the trial court to make an effective appointment of counsel was . . . a denial of due process. ${ }^{n 46}$

The notion that counsel is necessary to preserve reliable results in criminal prosecutions was reaffirmed in Johnson $v$. Zerbst, ${ }^{47}$ another pre-Gideon case, in which the Court held that the Sixth Amendment guarantees the right to court-appointed counsel in all federal prosecutions. ${ }^{48}$ Echoing Powell, the Court stated that the

${ }^{14} I d$. at $68-69$.

${ }^{45} I d$. at 69.

${ }^{16} \mathrm{Id}$. at 71 .

17304 U.S. 458 (1938).

${ }^{48}$ See id. at 468 . The case reached the Supreme Court on a writ of habeas corpus relating to a conviction for "possessing and uttering counterfeit money." Id. at 459. The Court reversed the denial of the petitioner's writ of habeas corpus and remanded for findings of waiver, holding that the violation of the Sixth Amendment's right to counsel would stand as a jurisdictional bar to a valid conviction and thus constituted grounds for granting the writ. See id. The Court later abandoned this jurisdictional construct as the basis for granting the federal writ of habeas corpus in Waley $v$. Johnston, 316 U.S. 101, 104-05 (1942) (" $[\mathrm{T}]$ he use of the writ in the federal courts to test the constitutional validity of a conviction for crime is not restricted to those cases where the judgment of conviction is void for want of jurisdiction of the trial 
Sixth Amendment embodies the recognition of the "obvious truth that the average defendant does not have the professional legal skill to protect himself when brought before a tribunal with power to take his life or liberty, wherein the prosecution is presented by experienced and learned counsel. ${ }^{\text {49 }}$

In Gideon, the Court emphasized the crucial role that defense counsel plays in preserving reliability within the nation's adversarial criminal justice system:

$[R]$ eason and reflection require us to recognize that in our adversary system of criminal justice, any person haled into court, who is too poor to hire a lawyer, cannot be assured a fair trial unless counsel is provided for him. This seems to us to be an obvious truth. ... That government hires lawyers to prosecute and defendants who have the money hire lawyers to defend are the strongest indications of the widespread belief that lawyers in criminal courts are necessities, not luxuries.... From the very beginning, our state and national constitutions and laws have laid great emphasis on procedural and substantive safeguards designed to assure fair trials before impartial tribunals in which every defendant stands equal before the law. This noble ideal cannot be realized if the poor man charged with crime has to face his accusers without a lawyer to assist him. ${ }^{50}$

In light of the "fundamental character"51 of the right to counsel, the Gideon Court held the Sixth Amendment applicable to the states through the Due Process Clause of the Fourteenth Amendment. ${ }^{52}$

Whereas Gideon, Powell, and Zerbst concerned felony trials, the Sixth Amendment's link between defense counsel and reliability also

court to render it."). The Court recently revived the jurisdictional-defect theory in Custis v. United States, 114 S. Ct. 1732 (1994), in which the Court limited the right to collaterally attack the validity of prior convictions in a sentencing proceeding under the Armed Career Criminal Act, 18 U.S.C. \$ 924(e) (1994), to those convictions in which the defendant was not appointed counsel in violation of Gideon. See Custis, 114 S. Ct. at 1738. The Court characterized the failure to appoint counsel as a "unique constitutional defect," and denied petitioner's claim that he should be allowed to challenge his prior convictions on the basis of ineffective assistance of counsel and incompetent guilty plea because they were not constitutional violations that rose to the level of a uurisdictional defect resulting from the failure to appoint counsel at all." Id. (citing Johnson v. Zerbst, 304 U.S. 458 (1938)). Justice Souter, in dissent, criticized the majority for reviving the jurisdictional- defect theory, referring to the difficulties that had led to its abandonment 50 years before. See id. at $1744-45$ (Souter, J., dissenting).

49 Zerbst, 304 U.S. at $462-63$.

${ }^{50}$ Gideon v. Wainwright, 372 U.S. 335, 344 (1963).

${ }^{51} \mathrm{Id}$. at 343 (quoting Powell v. Alabama, 287 U.S. 45, 68 (1932)).

52 See id. at 338-39. 
extends to misdemeanor prosecutions and guilty pleas. In Argersinger $v$. Hamlin, ${ }^{53}$ the Court held that no defendant may be sentenced to a prison term unless provided the assistance of counsel, regardless of whether the offense was classified as petty, misdemeanor, or felony. ${ }^{54}$ The Court explained that the rationale advanced in Powell and Gideon was not based solely on the classification of a case as a "felony," but rather applied to any criminal trial in which an "accused is deprived of his liberty." 55 Counsel might be necessary to a fair trial even in petty cases involving only brief periods of incarceration because legal and constitutional issues are not necessarily less complex in petty cases than in felony cases. ${ }^{56}$

The Court also noted its concern for cases that never go to trial. The assistance of counsel might be necessary to ensure that defendants make informed choices about the decision to plead guilty-a problem of serious concern in misdemeanor cases. ${ }^{57}$ The Court explained that the large volume of misdemeanor cases in overcrowded dockets could lead to a type of "assembly-line justice," in which fairness is sacrificed in the effort to move cases efficiently. ${ }^{58}$

The Argersinger Court limited its holding, however, to those misdemeanor defendants actually sentenced to a term of imprisonment, noting that it did not need to reach a question that was not

53407 U.S. 25 (1972).

${ }^{54}$ See id. at 37 . In a long concurring opinion, Justice Powell argued that the right to counsel should be co-extensive with the right to a jury trial, which applied to offenses authorizing imprisonment of six months or more, because the right to a jury trial would be of little use without the assistance of defense counsel. For offenses authorizing less than six months of imprisonment, he suggested that counsel should be appointed only when necessary to a fair trial, in essence, urging a return to the Betts v. Brady, 316 U.S. 455 (1942), standard for petty offenses. See Argersinger, 407 U.S. at 45-47 (Powell, J., concurring). Justice Powell also warned that the majority's reasoning would inevitably extend the right to all criminal offenses, that the Argersinger rule would force judges to effectively overrule legislative determinations that imprisonment should be an option in those cases in which judges decide not to, or are unable to, appoint counsel, and that many communities, particularly rural communities, would be unable to enforce their laws because of a dearth of legal resources. See id. at 51, 54-55, 61 (Powell, J., concurring).

${ }^{55}$ Argersinger, 407 U.S. at 32.

${ }^{56}$ See id. at 33 (citing vagrancy cases as an example of minor offenses involving potentially complex constitutional questions).

${ }^{37}$ See id. at 34.

${ }^{58} \mathrm{See} i d$. In support of the proposition that counsel may be instrumental in misdemeanor pleas, the Court referred to a study conducted by the American Civil Liberties Union that found represented misdemeanants were five times as likely as unrepresented misdemeanants to have all charges dropped. See id. at 36. 
then before the Court. ${ }^{59}$ Although the language of the opinion was sometimes phrased in terms of those misdemeanors involving actual imprisonment, the Court offered no reason why concerns about legal complexity and "assembly-line justice" would not apply equally to those misdemeanors ultimately receiving a disposition other than incarceration.

The Court's Sixth Amendment jurisprudence thus articulates a constant concern that our adversarial system of criminal justice depends too heavily on the efforts and knowledge of defense counsel to trust the ability of the process to function reliably in the absence of such counsel. In both felonies and misdemeanors, both before and during trial, there is simply too much in terms of legal knowledge and investigatory technique for the untrained defendant to handle competently.

\section{The Consequences of Conviction to the Defendant: The Requirement of Actual Imprisonment}

Although emphasizing the need for counsel in misdemeanor convictions, the Argersinger Court also placed a more conspicuous emphasis on the result of conviction. It specifically mentioned imprisonment several times, and it concluded by highlighting the limitation of its holding to the facts before it-an indigent defendant sentenced to a jail sentence for a misdemeanor conviction. ${ }^{60}$

${ }^{59}$ See id. at 37 . The actual incarceration standard introduced by the holding in Argersinger has been criticized as an abandonment of the fair-trial rationale underlying the right to counsel. See, e.g., Barbara B. Ford, Note, Argersinger v. Hamlin and the Collateral Use of Prior Misdemeanor Convictions of Indigents Unrepresented By Counsel at Trial, 35 OHIO ST. L.J. 168, 173 (1974) ("The unfairness of a misdemeanor trial without counsel is the basic reason for the Court's holding. Yet it abandoned this reasoning when it attached the right to counsel to the type of sentence imposed."); cf. id. at 169 (" Argersinger's] holding is narrow; it creates only the negative right not to go to jail without counsel at trial, rather than the affirmative right to counsel."). Other commentators have taken a more sympathetic view of the Court's holding, regarding it as a delicate compromise between the individual and the states. See, e.g., Lawrence Herman \& Charles A. Thompson, Scott v. Illinois and the Right to Counsel: A Decision in Search of a Doctrine?, 17 AM. CRIM. L. REv. 71, 77 (1979) ("Argersinger was a statesmanlike decision. It continued the evolution of the right to counsel, avoided what might rationally be regarded as the worst consequence of a misdemeanor conviction, but did not impose an unmanageable burden on the states.").

${ }^{60}$ The Court stated that it would not reach the question whether the right to counsel applies to misdemeanor cases not resulting in imprisonment because that question was not then before the Court. See supra note 59 and accompanying text. It did note that imprisonment, however short, would not likely be taken lightly by the accused, and it further stated that its decision would not affect the "run of misdemeanors." Following its decision, judges would know that defendants could not 
This focus on the consequences of conviction became more pronounced in the Court's next treatment of the issue, Scott $v$. Illinois, ${ }^{61}$ a case in which the defendant was found guilty of theft but was fined fifty dollars rather than sentenced to jail. ${ }^{62}$ Without ever denying the need for reliability in criminal cases, the Scott Court took greater notice of the potentially substantial burden that an extension of the right to counsel would place on the states. The focus of the holding, therefore, centered on the severity of the sentence imposed. The Court drew the line at actual imprisonment, holding that the Sixth and Fourteenth Amendments only require that indigent defendants not be sentenced to a term of imprisonment unless they were afforded the right to appointed counsel. ${ }^{63}$ Under this holding, Scott's conviction leading only to a

be sent to jail if unrepresented and would thus have an opportunity to measure the seriousness of the offense before trial to decide whether counsel should be appointed or not. See Argersinger, 407 U.S. at 37, 40.

61440 U.S. 367 (1979).

${ }^{62}$ See id. at 368.

${ }^{63}$ See id. at 373-74. Justice Brennan, in dissent, argued for an "authorized imprisonment" standard, rather than the majority's "actual imprisonment" standard. Justice Brennan observed that the stigma, collateral consequences, and applicable procedural rules depend on the potential penalty for an offense, rather than the actual sentence imposed. Moreover, offenses authorizing incarceration possess the characteristics found by Gideon to require counsel. Furthermore, the authorized imprisonment standard would be easier to apply administratively and would not involve the problems raised by Justice Powell's Argersinger concurrence concerning the de facto overruling of legislative choices. See supra note 54. Finally, the Court's concern about the economic burdens implicated by an expansion of the constitutional right to counsel was both speculative and irrelevant; constitutional guarantees for criminal defendants should not depend upon state budgetary concerns. See Scott, 440 U.S. at 382-84 (Brennan, J., dissenting).

Justice Brennan also argued that, in any case, the Court did not need to reach the question whether actual imprisonment was the constitutional limit to the right to counsel because Scott had been charged with an offense authorizing up to one year of imprisonment. Because this offense was nonpetty, Scott had the right to a jury trial, and because Argersinger noted that the right to counsel was more fundamental to a fair trial than the right to a jury trial, it must follow that Scott also had an absolute right to counsel. Otherwise, the Court would set up the anomalous result that Scott could have a jury trial, but could not obtain counsel to present his defense to the jury. See id. at 380-82 (Brennan, J., dissenting).

Justice Blackmun, in dissent, argued for an absolute right to counsel in cases involving authorized punishment of six months or more, and an actual imprisonment standard for offenses involving lesser, petty, offenses. See id. at 389-90 (Blackmun, J., dissenting).

The American Bar Association (ABA) supports an authorized imprisonment standard. The ABA recommends that "[c]ounsel should be provided in all proceedings for offenses punishable by death or incarceration, regardless of their denomination as felonies, misdemeanors, or otherwise." ABA STANDARDS FOR 
fine did not give him a constitutional right to court-appointed counsel. ${ }^{64}$

The Court observed that Argersinger rejected concerns about social cost or the lack of available lawyers because it concluded that incarceration was too severe a sanction to impose on a criminal defendant who did not have an opportunity to retain courtappointed counsel for his defense. ${ }^{65}$ The several references in Argersinger to the severity of incarceration, although not absolutely clear, convinced the Scott Court that Argersinger intended to limit the right accordingly. ${ }^{66}$ The Court further explained that even if the issue were a matter of first impression, it would adhere to the central premise of Argersinger-that incarceration is a penalty different in kind from fines or the mere threat of incarceration. ${ }^{67}$

Thus, the Court distinguished between misdemeanor convictions that net defendants time in prison and those that net lesser penalties, such as fines or probation. Its reason for doing so was not that the latter convictions have a reduced need for counsel to preserve the reliability of the adjudication. Rather, the Court's focus on the consequences of conviction must be understood as one

Criminal Justice: Providing Defense Services Standard 5-5.1 (American Bar Ass'n 1992) [hereinafter STANDARDS FOR CRIMINAL JUSTICE]. The ABA explained that an authorized imprisonment standard should be adopted because

no other suggested formulation for implementing the Argersinger decision is satisfactory. A "classification of offense" standard, whereby courts determine never to impose imprisonment for certain misdemeanors and petty offenses and thus withhold providing counsel in these cases, is tantamount to judicial repeal of the legislature's penalty provision of incarceration. A "predetermination procedure," ... by which the court confers with the prosecutor in advance of the proceeding to determine the likelihood of imprisonment being imposed, is also rejected. In addition to being time-consuming, there is substantial risk that the court will receive information about the defendant or the offense charged which will make it exceedingly difficult for the judge to sit as fair and impartial arbiter, regardless of whether it is determined that counsel should be provided.

Id. commentary.

is See Scott, 440 U.S. at 374.

${ }^{65}$ See id. at $372-73$.

${ }^{66}$ See id. at 373. The Court observed that the petitioners in Argersinger had urged a broader right that would apply to any case in which imprisonment was authorized, even if not imposed, whereas the respondents had argued for a right that would attach only to cases in which imprisonment for six months or more was authorized. Aware of these alternatives, the Court in Argersinger adopted the Solicitor General's standard of actual imprisonment. See id. at 373 n.4.

${ }^{67}$ See id. at 373. 
side of a balance, the other being the burden imposed on the states by any expansion in the right to court-appointed counsel.

\section{The Burden to the States of Compliance with the} Right to Court-Appointed Counsel

Just as the focus on the consequences of conviction came to the forefront in Scott, so too did the accompanying focus on the possible burdens any expanded right to counsel might entail for the state governments that must implement that right.

The Scott decision appears to have been motivated by several concerns. One set of concerns involves issues of constitutional interpretation and judicial restraint. The Court expressed considerable doubt whether the Sixth Amendment was originally intended by its framers to guarantee anything other than the right of a criminal defendant to be represented by a privately hired lawyer. ${ }^{68}$ Noting the number of separate opinions filed in recent Sixth Amendment cases, the Court warned that "constitutional line drawing becomes more difficult as the reach of the Constitution is extended further. ${ }^{n 9}$ Although the central premise of Gideon remained clear, the Court was unwilling to extend the principle further in light of its uncertain limits and ramifications, particularly because the literal and common law understandings of the Sixth Amendment had already been abandoned. ${ }^{70}$

The Court's hesitance to issue a constitutional mandate without clearer guidance was accentuated by concerns of federalism. Incorporation of federal guarantees into the Fourteenth Amendment's notion of due process raised special difficulties because application of the same principle would have different ramifications in the context of state, versus federal, laws. ${ }^{71}$ State criminal laws regulate a far broader range of human conduct than federal

\section{${ }^{63}$ See id. at 370.}

${ }^{69}$ Id. at 372 (referring to Gideon, Argersinger, Duncan v. Louisiana, 391 U.S. 145 (1968), and Baldwin v. New York, 399 U.S. 66 (1970)).

${ }^{70}$ See id. The common law understanding was rejected because it gave a broader right to counsel in misdemeanor prosecutions than in felony convictions. See id. (citing Powell v. Alabama, 287 U.S. 45, 60 (1932)). Under the original common law rule that existed in England at the time the Constitution was adopted, a defendant charged with a felony was not permitted to obtain the assistance of a lawyer except for the limited purpose of receiving answers to legal questions raised by the defendant himself. See Powell, 287 U.S. at 60. Defendants charged with misdemeanors, on the other hand, were permitted full representation by lawyers. See id.

"I See Scott, 440 U.S. at 372. 
criminal laws, particularly on the petty or misdemeanor level. ${ }^{72}$ Although Argersinger had proven fairly workable, the Court reasoned that any extension would create confusion and impose unpredictable, but substantial, costs on the states. ${ }^{73}$ In light of the potentially burdensome costs that any expansion of the right to appointed counsel would impose on the states, and in light of the lesser penalties involved in nonimprisonment sentences, the Court drew the line at actual imprisonment as the limit to the constitutional right to court-appointed counsel. ${ }^{74}$

\section{B. Sentence Enhancement and Gideon}

Argersinger and Scott grappled with one question raised by Gideon: To what range of criminal prosecutions does the constitutional right extend? Another question left open by Gideon concerned the collateral use of uncounseled convictions: When, if ever, can an uncounseled conviction serve as the basis for enhancing the sentence of a subsequent conviction?

${ }^{72}$ See id.

${ }^{73}$ See id. at 373. Many commentators, including Justice Brennan in dissent, have concluded that the Court's decision in Scott was largely motivated by the belief that extending the right to counsel to misdemeanors merely authorizing imprisonment would impose a substantial economic burden on the state governments that would have to pay for the additional ranks of defense counsel. See, e.g., id. at 384 (Brennan, J., dissenting); Herman \& Thompson, supra note 59, at 93 (concluding that the Court in Scott "apparently based [the] decision not to extend the right to counsel on an undocumented fear of the economic costs that such an extension would impose on the states"); $c f$. WAYNE R. LAFAVE \& JEROLD H. ISRAel, Criminal Procedure $\$ 1.6(\mathrm{a})$, at 34-35 (2d ed. 1992) (stating that a "factor sometimes balanced against the truth-seeking goal of the process, although usually not with such open recognition, is the limitations of available administrative resources" and that "some courts have recognized that those pressures have played a significant role in shaping the law governing such subjects as ... the provision of appointed counsel for indigent offenders-arguably at some cost to the reliability of the adjudicatory process"); Ford, supra note 59, at 175 (stating that a "tenable theory" for explaining Argersinger's focus on the sentencing process is that the Court was attempting "to balance the competing views that all indigents charged with a misdemeanor have a right to court-appointed counsel . . . because uncounseled trials are unfair and unreliable, and that the administration of justice would be adversely affected by such a broad extension of the right to counsel" (footnotes omitted)).

7 See Scott, 440 U.S. at 373. Although a literal reading of Scott might suggest that even defendants charged with felonies have no constitutional right to counsel if they do not receive a term of imprisonment, the Court reaffirmed the general understanding that Gideon applies to all felonies, regardless of the sentence imposed. See Nichols v. United States, 114 S. Ct. 1921, 1925 n.9 (1994). 


\section{Uncounseled Convictions That Violate the Gideon Principle}

The Supreme Court first addressed the collateral use of uncounseled convictions in Burgett $v$. Texas. ${ }^{75}$ In Burgett, the defendant challenged the introduction at trial of evidence of four prior felony convictions, all of which were obtained without the aid of counsel. $^{76}$ Texas's recidivist statute provided that defendants should receive the maximum penalty for an offense if they had previously been convicted of a similar offense and required life imprisonment upon the third felony conviction. ${ }^{77}$ The prosecution presented evidence of the prior convictions to the jury pursuant to the statute. ${ }^{78}$ The trial judge later determined that the prosecution could not meet its burden under the recidivist statute and instructed the jury to disregard the prior convictions. ${ }^{79}$ The jury found Burgett guilty and sentenced him to ten years in prison, rather than the maximum penalty of twenty-five years. ${ }^{80}$

On appeal, the Supreme Court reversed Burgett's conviction. ${ }^{81}$ Although the jury did not enhance Burgett's sentence, the Court feared that the jury had found Burgett guilty on the basis of his criminal record rather than on the evidence of the assault charge. ${ }^{82}$

${ }^{75} 389$ U.S. 109 (1967).

${ }^{76}$ See id. at 111-12 (stating there was no indication in the record that counsel had been waived in the case of the defendant's four prior felony convictions: one conviction for burglary and three convictions for forgery).

77 See id. at 111 n.3.

${ }^{78}$ See id.

${ }^{79}$ See id. at $113 \&$ n.6. In a hearing outside the presence of the jury, the trial judge determined that the defendant's prior Texas conviction for burglary was void under state law and that the defendant's three Tennessee convictions for forgery qualified as only one conviction for purposes of Texas's recidivist statute because all three convictions were obtained on the same date. The defendant therefore could not be prosecuted under Texas's recidivist statute because he did not have two prior felonies nor was the prior forgery conviction similar to the assault offense for which he was currently being tried. See id. at $112-13$ \& n.6. The trial judge did not explain why the prosecution could not use the prior convictions when he instructed it to disregard them. See id. at 118-19 (Warren, C.J., dissenting).

${ }^{80}$ See id. at $110 \&$ n.l.

${ }^{81}$ See id. at 116.

${ }^{82}$ See id. at $115 \& \mathrm{n} .7$ (stating that the admission at trial of a conviction invalid under Gideon would be "inherently prejudicial" and quoting Justice Jackson's statement that " $[t]$ he naive assumption that prejudicial effects can be overcome by instructions to the jury ... all practicing lawyers know to be unmitigated fiction" (quoting Krulewitch v. United States, 336 U.S. 440, 453 (1949) (Jackson, J., concurring)) (second alteration in original)); $i d$. at 119 (Warren, C.J., concurring) ("To expect that the jury could wipe [the invalid convictions] from its memory and decide 
The Court explained that the defendant's conviction had to be reversed because using convictions obtained in violation of Gideon "to support guilt or enhance punishment for another offense" would "erode the principle" of Gideon. ${ }^{83}$ Permitting such use would force the defendant to "suffer[] anew from the deprivation of that Sixth Amendment right. ${ }^{\text {84 }}$

The Court's next occasion to address the collateral use of uncounseled convictions arose five years later in United States $v$. Tucker. ${ }^{85}$ In Tucker, the sentencing judge expressly recognized two prior uncounseled felony convictions when imposing the maximum penalty of twenty-five years of imprisonment. ${ }^{86}$ The Supreme Court affirmed the lower court's judgment to remand the case to the district court for a redetermination of the defendant's sentence without consideration of the uncounseled convictions. ${ }^{87}$ The Court acknowledged that federal judges generally enjoy wide discretion in determining sentences and that few limits exist on the kind of information they may consider before imposing a sentence. ${ }^{88}$ The Court also acknowledged the then-existing principle (before the promulgation of the United States Sentencing Guidelines) that sentences are generally not reviewable as long as they are imposed within the statutory limits. ${ }^{89}$ In this case, however, the prior convictions had been obtained in violation of the right to counsel. Relying on Burgett, the Court stated that the use of these convictions

the petitioner's guilt only on the basis of the evidence of assault is to place too much faith in a jury's ability to detach itself from reality.").

${ }^{83}$ See id. at 115 .

${ }^{84}$ Id. Another application of the Burgett principle can be found in Loper v. Beto, 405 U.S. 473 (1972). In Loper, the defendant was charged with statutory rape, and the only question at trial was the credibility of the testimony offered by the defendant and his accuser. See Loper, 405 U.S. at 474 . To attack his credibility, the prosecution cross-examined the defendant about his four prior felony convictions, all of which had been obtained in violation of Gideon. See id. at 474, 476. The Court held that the defendant's conviction was invalid because the convictions were used to support guilt-the issue of guilt hinged on the defendant's credibility, and the convictions were entered solely to destroy his credibility. See id. at 482.

85404 U.S. 443 (1972).

${ }^{86}$ See id. at $444-45$.

${ }^{87}$ See id. at 449. The United States Court of Appeals for the Ninth Circuit had affirmed the district court's refusal to vacate the defendant's conviction, agreeing that the evidence of guilt was overwhelming, but had remanded the case to the district court for resentencing without any consideration of the prior uncounseled convictions. See id. at 445-46.

${ }^{83}$ See id. at 446 (citing Williams v. New York, 337 U.S. 241 (1949)).

${ }^{89} \mathrm{See} i d$. at 447. 
to enhance the defendant's sentence would erode the principle of Gideon and thus that the convictions could not be used. ${ }^{90}$

\section{Uncounseled Convictions That Do Not Violate the Gideon Principle: Baldasar $v$. Illinois}

Burgett and Tucker established the proposition that it is unconstitutional to support guilt or enhance punishment with a conviction obtained in violation of Gideon. What about uncounseled convictions that do not violate Gideon? A splintered Court addressed this question in Baldasar v. Illinois. ${ }^{91}$ At issue in Baldasar was the sentencing of the defendant under Illinois's recidivist statute. This statute converted a misdemeanor into a felony offense upon the second commission of the same offense..$^{92}$ On the basis of a prior, uncounseled misdemeanor conviction, the trial court converted Baldasar's current misdemeanor offense into a felony and sentenced him to a term of imprisonment. ${ }^{93}$

In a per curiam opinion, the Court reversed Baldasar's convic-

${ }^{90}$ See id. at 449 ("Erosion of the Gideon principle can be prevented here only by affirming the judgment of the Court of Appeals remanding this case to the trial court for reconsideration of the respondent's sentence.").

The Court also justified its decision by noting that the defendant's sentence was imposed "in part upon misinformation of constitutional magnitude." Id. at 447. Because the defendant's prior convictions were imposed in 1953, before Gideon had been decided, the sentencing judge had operated on the assumption that the defendant's prior convictions were constitutionally valid. See id. at 443, 447-48. It was not until much later, after Gideon had been declared retroactive, that these prior uncounseled felony convictions became constitutionally invalid. Thus, the sentencing judge thought he was sentencing a defendant with three prior felonies, but in fact he was sentencing a defendant with at least two prior unconstitutional convictions. See id. at 448. The Court relied on Townsend v. Burke, 334 U.S. 736 (1949), for the proposition that a defendant may not be sentenced on the basis of inaccurate information. See Tucker, 404 U.S. at 447. In Townsend, the Court had reversed a defendant's conviction as a violation of the Due Process Clause because the judge mistakenly believed that the defendant had previously been convicted of several offenses for which he had actually been acquitted. See id. at 740-41 (stating that the defendant "was sentenced on the basis of assumptions concerning his criminal record which were materially untrue" and that such a result was "inconsistent with due process of law"). The Court's Townsend rationale seems to suggest that as long as a judge determines a defendant's sentence on the basis of accurate information-in this case, knowledge that the two prior convictions were invalid-the judge may consider convictions invalid under Gideon. The Court's reliance on Burgett, however, to prohibit any consideration of uncounseled convictions for purposes of enhancement forecloses this possibility.

${ }^{91} 446$ U.S. 222 (1980) (per curiam).

${ }^{92}$ See id. at 223.

${ }^{95}$ See id. 
tion and remanded..$^{94}$ The per curiam opinion gave no reason for the decision, but instead referred to those stated in the three concurring opinions. ${ }^{95}$ Justice Stewart took the position that Baldasar's conviction was a clear violation of Scott because Baldasar received an enhanced term of imprisonment as a direct result of an uncounseled conviction. ${ }^{96}$

Justice Marshall, while acknowledging that Baldasar's enhanced prison sentence was not punishment for the original offense, stated that it was also clear that Baldasar had received an additional period of incarceration as a direct result of the uncounseled conviction. ${ }^{97}$ The rationale underlying Argersinger, according to Marshall, was that uncounseled convictions are too unreliable to support the severe sanction of imprisonment, and that any conviction too unreliable to support imprisonment in the first instance remains too unreliable to support imprisonment in the second, even in the form of a sentence enhancement. ${ }^{98}$

Justice Blackmun took the position that enhancement was invalid because Baldasar's original uncounseled misdemeanor conviction, being a nonpetty offense, would have been unconstitutional under the standard Blackmun proposed in his Scott dissent. ${ }^{99}$ In

${ }^{9}$ See id. at 224. The American Bar Association endorsed the result in Baldasar, recommending that counsel be provided for any offense in which "the fact of conviction may be established in a subsequent proceeding, thereby subjecting the defendant to incarceration." STANDARDS FOR CRIMINAL JUSTICE, supra note 63, Standard 5-5.1. The ABA explained that

counsel is required under this standard when a conviction can be used in a subsequent proceeding so as to apply a recidivist statute and thereby lead to imprisonment. Consistent with this standard, the Supreme Court has held in Baldasar $v$. Illinois that an uncounseled misdemeanor conviction, which did not result in incarceration, may not be used under an enhanced penalty statute to convert a subsequent misdemeanor offense into a felony.

Id. commentary (footnotes omitted).

${ }^{95}$ See Baldasar, 446 U.S. at 224.

${ }^{96}$ See id. (Stewart, J., concurring).

${ }^{97}$ See id. at 226-27 (Marshall, J., concurring) ("Solely because of the previous conviction the second offense was transformed from a misdemeanor into a felony, with all the serious collateral consequences that a felony conviction entails . ..."). Baldasar was sentenced to a term of one to three years of imprisonment, whereas the maximum penalty for the unenhanced misdemeanor was one year of imprisonment. See id. at 223, 227.

${ }^{98}$ See id. at 227-28 (Marshall, J., concurring) ("An uncounseled conviction does not become more reliable merely because the accused has been validly convicted of a subsequent offense.").

${ }^{99}$ See id. at 229-30 (Blackmun, J., concurring). 
Scott, Justice Blackmun had argued that counsel should be appointed for all offenses authorizing punishment of six months or more. ${ }^{100}$

Justice Powell, in dissent, argued that Scott was not implicated because recidivist statutes penalize the last offense only and do not alter or enlarge the sentence imposed for the original conviction. ${ }^{101}$ Justice Powell also argued that, as a matter of logic, constitutional convictions should be valid for sentence enhancement, just as unconstitutional convictions are invalid for sentence enhancement. He criticized the concurring Justices for creating a hybrid class of convictions that are valid for their own penalties but invalid for other purposes, such as enhancing punishment. ${ }^{102}$ Finally, Justice Powell argued that the decision would create confusion, burden the states, and deprive communities of the ability to enforce their recidivist statutes if they were unable to provide counsel to misdemeanants. ${ }^{103}$

\section{NICHOLS V. UNITED STATES ${ }^{104}$}

The Baldasar decision enjoyed a rocky reception in the state and lower federal courts. The decision proved confusing because none of the three concurring opinions commanded a majority of the Court, nor did any controlling principles emerge from the various disjointed opinions. This confusion resulted in widely varying outcomes among the state and federal courts. Some courts limited Baldasar to its facts, while others construed it to bar the collateral enhancement of any uncounseled conviction. ${ }^{105}$ To resolve these conflicts, the Court granted certiorari in Nichols v. United States. ${ }^{106}$

${ }^{100}$ See Scott v. Illinois, 440 U.S. 367, 389 (1979) (Blackmun, J., dissenting).

${ }^{101}$ See Baldasar, 446 U.S. at 232 (Powell, J., dissenting).

102 See id. at 232-33 (Powell, J., dissenting).

${ }^{103}$ See id. at 234-35 (Powell, J., dissenting).

104 114 S. Ct. 1921 (1994).

105 Compare United States v. Brady, 928 F.2d 844, 854 (9th Cir. 1991) (holding that Baldasar prohibits sentence enhancement based on uncounseled misdemeanor convictions) and Lovell v. State, 678 S.W.2d 318, 320 (Ark. 1984) (same) with Wilson v. Estelle, 625 F.2d 1158, 1159 \& n.1 (5th Cir. 1980) (holding that Baldasar applies only when an uncounseled misdemeanor conviction is used to convert a second misdemeanor offense into a felony), cert. denied, 451 U.S. 912 (1981), and Hlad v. State, 565 So. 2d 762, 764-66 (Fla. Dist. Ct. App. 1990) (adopting Justice Blackmun's approach). For a discussion of the difficulties experienced by the lower courts in applying Baldasar, see Lily Fu, Note, High Crimes from Misdemeanors: The Collateral Use of Prior, Uncounseled Misdemeanors Under the Sixth Amendment, Baldasar and the Federal Sentencing Guidelines, 77 MINN. L. REV. 165 (1992).

${ }^{106}$ See Nichols, 114 S. Ct. at 1925 \& nn.7-8 (discussing the confusion in the state courts). 
After pleading guilty to drug conspiracy charges, Nichols was sentenced under the Federal Sentencing Guidelines ${ }^{107}$ to 235 months in prison. ${ }^{108}$ In determining his sentence, the trial court assigned to Nichols four criminal history points, three for a federal felony drug conviction and one for a state misdemeanor conviction (driving under the influence). ${ }^{109}$ Nichols objected to the inclusion of the misdemeanor charge because he had not been represented by counsel. ${ }^{110}$ Noting that the conviction was valid under Scott because Nichols had merely been fined, the district court rejected his Sixth Amendment claim. ${ }^{111}$ The district court confined Baldasar to enhancement proceedings that convert misdemeanors into felonies; because Nichols's current charge was already a felony, the decision was inapplicable. ${ }^{112}$ The additional criminal history point attributed to his misdemeanor conviction moved Nichols into the next category, increasing his sentencing range from 168-210 months to $188-235$ months. ${ }^{13}$ The sentencing judge entered the maximum penalty, thereby increasing Nichols's sentence to twentyfive months beyond the maximum sentence that he could have received without the consideration of his uncounseled conviction. ${ }^{114}$

The Supreme Court affirmed Nichols's sentence, holding that uncounseled misdemeanor convictions that are valid under Scott are just as valid for the purpose of enhancing the punishment imposed in a subsequent conviction. ${ }^{115}$ The Court gave

${ }^{107}$ The Federal Sentencing Guidelines were promulgated by the United States Sentencing Commission, an independent agency of the judicial branch, pursuant to the Sentencing Reform Act of 1984, Pub. L. No. 98-473, §§ 211-238, 98 Stat. 1837, $1987-2040$ (codified at 18 U.S.C. $\$ \S 3551-3625,3673,3742,5037$ (1994) and 28 U.S.C. $\$ \S 991-998$ (1994)). The Guidelines set forth a detailed grid of presumptive sentencing ranges that matches a calculated offense level against an offender's criminal history category, which is determined by the number of criminal history points assigned to the defendant under chapter 4, part A. See U.S. SENTENCING COMM'N, GUIDELINES MANUAL \$§ 4A1.1-.3, 5A (1993).

${ }^{108}$ See Nichols, 114 S. Ct. at 1924-25.

${ }^{109}$ See id. at 1924. Both convictions were obtained in 1983. Nichols pleaded guilty to the current offense, conspiracy to possess cocaine with intent to distribute, in 1990. See id.

${ }^{110}$ See id.

"II See id.

112 See id.

11 See id.

${ }^{114}$ See id. at 1925.

${ }^{115}$ See id. at 1928. Baldasar merited reexamination because the lack of consensus among the concurring opinions defied the normal rule of construction for splintered decisions-that the narrowest ground for concurrence governs. See id. 
three justifications for its decision. First, a "logical consequence" of Scott is that if uncounseled convictions are constitutionally valid under Scott, they also are valid for the purpose of enhancing the sentence of a subsequent offense, even if the enhanced sentence entails imprisonment. ${ }^{116}$ Second, as explained in Moore $v$. Missouri $^{117}$ and similar Court precedents, enhancement statutes do not change the penalty imposed for the earlier conviction but merely penalize the last offense committed. ${ }^{118}$ Third, reliance upon uncounseled convictions valid under Scott is consistent with the traditional understanding of the sentencing process, which has been recognized as less exacting than the process of first establishing guilt. ${ }^{119}$

The Court expanded upon this last point by observing that sentencing judges have authority to engage in a broad inquiry, with few limitations on the kind of information that may be considered or the source from which it may come. ${ }^{120} \mathrm{~A}$ defendant's prior convictions have always been considered important in the sentencing determination. Furthermore, courts are not limited to considering criminal behavior for which a defendant has actually been convicted; they may, consistently with due process, consider past criminal behavior for which the defendant has never been con-

at $1926-27$.

${ }^{116}$ See id. at 1927 (" $[\mathrm{W}] \mathrm{e}$. . . agree with the dissent in Baldasar that . . an uncounseled conviction valid under Scott may be relied upon to enhance the sentence for a subsequent offense, even though that sentence entails imprisonment."). Justice Powell's Baldasar dissent is discussed supra text accompanying notes 101-03.

117159 U.S. 673 (1895). The Court cited to Moore and Oyler v. Boles, 368 U.S. 448 (1962). See Nichols, 114 S. Ct. at 1927. Moore upheld a recidivist statute challenged under the Double Jeopardy Clause. See Moore, 159 U.S. at 677. For a brief discussion of Moore and other Court precedents adhering to the view that recidivist statutes punish only the last offense, see supra notes 25-30 and accompanying text.

${ }^{118}$ The Court explained:

Enhancement statutes, whether in the nature of criminal history provisions such as those contained in the Sentencing Guidelines, or recidivist statutes which are common place in state criminal laws, do not change the penalty imposed for the earlier conviction. As pointed out in the dissenting opinion in Baldasar, "[t]his Court consistently has sustained repeat-offender laws as penalizing only the last offense committed by the defendant."

Nichols, 114 S. Ct. at 1927 (quoting Baldasar v. Illinois, 446 U.S. 222, 232 (1980) (per curiam) (alteration in original).

${ }^{119}$ See id.

${ }^{120}$ See id. at 1927-28 (citing Tucker, discussed supra text accompanying notes 85-90, which, in turn, relied on Williams v. New York, 337 U.S. 241 (1949)). 
victed. ${ }^{121}$ Moreover, the Due Process Clause requires only that the state prove such nonconvicted criminal behavior at a sentencing proceeding by a preponderance of the evidence. ${ }^{122}$ Thus, the district court could have sentenced Nichols to a more severe prison sentence based simply on evidence of the criminal behavior (drinking and driving) underlying his misdemeanor conviction by a preponderance of the evidence at the sentencing proceeding. "Surely, then, it must be constitutionally permissible to consider a prior uncounseled misdemeanor conviction based on the same conduct where that conduct must be proven beyond a reasonable doubt." 123

Justice Souter, in concurrence, approved the use of uncounseled misdemeanor convictions in sentence-enhancement proceedings under the Federal Sentencing Guidelines because the Guidelines prescribed presumptive sentences only. The Guidelines' provisions for downward departures provided a defendant with an opportunity to convince the judge that his sentence should be reduced because of the unreliability of a prior uncounseled conviction. ${ }^{124}$ Justice Souter explained that as long as the "concern for reliability is accommodated, as it is under the Sentencing Guidelines, nothing in the Sixth Amendment or our cases requires a sentencing court to ignore the fact of a valid uncounseled conviction. ${ }^{n 25} \mathrm{He}$ did not join in the majority's opinion, however, because that opinion seemed to apply equally to sentencing schemes that require automatic enhancement for uncounseled convictions and thus contain no provision to accommodate the Sixth Amendment's concern for reliability. ${ }^{126}$ Souter emphasized that "a sentencing scheme that automatically requires enhancement for

${ }^{121}$ See id. at 1928 (citing Williams, 337 U.S. 241).

122 See id.

${ }^{123} \mathrm{Id}$.

${ }^{124}$ See id. at 1930 (Souter, J., concurring). The Guidelines allow a judge to consider a downward departure when the judge concludes that a defendant's criminal history category "significantly over-represents the seriousness of a defendant's criminal history or the likelihood that the defendant will commit further crimes." U.S. SENTENCING COMM'N, GUIDELINES MANUAL § 4A1.3 (1993). Justice Blackmun did "not share Justice Souter's confidence that such a benevolent review of a defendant's circumstances is occurring now. . . . Accordingly," he argued, "the district court's authority to depart downward [is] too tenuous a check on the use of unreliable misdemeanor convictions ...." Nichols, 114 S. Ct. at 1935 n.4 (Blackmun, J., dissenting).

${ }^{125}$ Nichols, 114 S. Ct. at 1930 (Souter, J., concurring).

${ }^{126}$ See id. at 1931 (Souter, J., concurring). 
prior valid but uncounseled convictions ... [is] a scheme not now before us." 127

Justice Blackmun, in dissent, argued that uncounseled misdemeanor convictions should be invalid for enhancing prison sentences, just as they are invalid for imposing terms of imprisonment in the initial instance. ${ }^{128}$ He found this position more logical than the majority's and better suited to the Sixth Amendment's concern for reliability. Although not punishment for the original offense according to Moore, Nichols's sentence was undeniably enhanced by more than two years as a direct result of his prior uncounseled conviction. ${ }^{129}$ Because imprisonment was a penalty "different in kind" from fines or threatened imprisonment, the Court had always required the appointment of counsel under the Sixth Amendment to decrease the risk of unreliability. ${ }^{130}$ Finally, Justice Blackmun argued that the mere submission of a record of conviction does not require the state to prove that the conviction reliably reflects the defendant's past criminal conduct. At the same time, the record of a past criminal conviction generally carries greater weight than other evidence of prior conduct. $^{131}$

${ }^{127}$ Id. Justice Souter suggested that there was "an obvious and serious argument that the line in Scott is crossed" when a defendant's sentence is enhanced on the basis of an uncounseled conviction under an automatic sentencing scheme. Id. at 1929 (Souter, J., concurring).

${ }^{128}$ See id. at 1935-36 (Blackmun, J., dissenting). Acknowledging that such a rule might force the states to appoint counsel to more indigents so as to preserve the right to enhance the sentence of a potential conviction in the future, Justice Blackmun asserted that the Sixth Amendment right to counsel should not be subordinated to costs. See id. at 1936 (Blackmun, J., dissenting).

${ }^{129}$ See id. at 1933 (Blackmun, J., dissenting) ("That the sentence in Scott was imposed in the first instance and the sentence here was the result of an enhancement statute is a distinction without a constitutional difference.").

${ }^{130} \mathrm{See}$ id. (Blackmun, J., dissenting).

${ }^{131}$ See id. at 1934-35 \& n.4 (Blackmun, J., dissenting). Justice Blackmun observed that when the state seeks to prove actual criminal conduct, rather than the fact of conviction, the defendant has an opportunity to test the state's evidence with the aid of counsel at the sentencing proceeding. The fact of conviction, on the other hand, generally carries presumptive weight, as under the Guidelines where convictions are assigned criminal history points that determine the defendant's criminal history category and sentencing range. Justice Blackmun disagreed with Justice Souter's conclusion that the Guidelines' downward-departure provisions adequately accommodated the Sixth Amendment's reliability concerns. Not only are uncounseled convictions difficult to prove unreliable after the fact, but the Guidelines caution that departures from the presumptive sentence ranges should be considered only in "atypical" cases, outside the "heartland" carved by each guideline. See id. (Blackmun, J., dissenting) (referring to Guidelines ManUaL ch. 1, 


\section{Nichols: IN SEARCH OF A RATIONALE}

The Supreme Court reconsidered its decision in Baldasar in order to clarify a confused area of Sixth Amendment law and responded by overruling it. Under Nichols, an uncounseled misdemeanor conviction may be used to enhance the sentence of a subsequent conviction as long as the uncounseled conviction was valid under Scott. The Court justified its decision by arguing that enhancement does not violate Scott because it punishes only the last offense, that enhancement based on valid convictions does not violate Tucker, and that consideration of uncounseled convictions is consistent with the standards of due process at sentencing. All three justifications prove problematic upon examination.

\section{A. The Minimal Requirements of Due Process at Sentencing}

The Court's due process argument will be considered first because it is of only secondary importance to the central and dispositive Sixth Amendment principles. This argument asserts that courts may consider uncounseled misdemeanor convictions at sentencing because the requirements of due process are less demanding at the sentencing stage than at the guilt-determination stage. ${ }^{132}$ At sentencing, due process requires only that criminal conduct be established by a preponderance of the evidence; because criminal convictions have been proven beyond a reasonable doubt, they easily satisfy the requirements of due process. Therefore, this argument asserts, courts may rely upon uncounseled convictions when determining the appropriate sentence for a defendant.

This argument establishes no more than the trivial point that proof beyond a reasonable doubt is a greater burden of proof than proof by a preponderance of the evidence. The Court is correct in asserting that the district court could have enhanced Nichols's sentence if the prosecution had offered proof at the sentencing proceeding of the underlying conduct that gave rise to his uncounseled drunk driving conviction. ${ }^{133}$ The Court correctly

pt. A, 4(b)).

${ }_{132}$ See supra notes $119-23$ and accompanying text.

133 Sentencing courts may consider criminal conduct for which the defendant has never been formally convicted. See infra notes 134-36. As the Court states, the prosecution could have offered evidence, independent of Nichols's drunk driving conviction, that demonstrated that Nichols had been out drinking and driving one night in Georgia several years before, just as it could if Nichols had never been convicted for the conduct. See Nichols, $114 \mathrm{~S}$. Ct. at 1928. The requirements of due 
relies on Williams v. New York ${ }^{134}$ and McMillan v. Pennsylvania ${ }^{135}$

process are relaxed enough at sentencing that even criminal conduct for which the defendant has been tried and acquitted may be considered. Although the Supreme Court has not addressed the question whether acquitted conduct may be considered at sentencing, most of the federal circuits have concluded that it can. See, e.g., United States v. Rodriguez-Gonzalez, 899 F.2d 177, 182 (2d Cir.), cert. denied, 498 U.S. 844 (1990); United States v. Dawn, 897 F.2d 1444, 1449-50 (8th Cir.), cert. denied, 498 U.S. 960 (1990); United States v. Mocciola, 891 F.2d 13, $16-17$ (1st Cir. 1989); United States v. Ryan, 866 F.2d 604, 609 (3d Cir. 1989); United States v. Juarez-Ortega, 866 F.2d 747, 749 (5th Cir. 1989); cf. United States v. Clark, 613 F.2d 391, $402-03$ (2d Cir. 1979) (holding that the acquittal of conspiracy charges did not preclude admission of hearsay statements of co-conspirators at a subsequent trial on the substantive offenses); Standlee v. Rhay, 557 F.2d 1303, 1307 (9th Cir. 1977) (holding that the acquittal of criminal charges does not preclude revocation of parole for the same acts because of the different burdens of proof). But see United States v. Brady, 928 F.2d 844, 851-52 (9th Cir. 1991) (holding that a sentencing judge may not enhance a sentence on the basis of facts that a jury must have rejected in order to reach acquittal).

The Court has upheld the use of acquitted conduct in other contexts. See, e.g., Dowling v. United States, 493 U.S. 342, 348-50 (1990) (holding that acquitted criminal conduct could be admitted in a criminal prosecution under Rule 404(b) of the Federal Rules of Evidence because of the burden of proof differential between a criminal conviction and admission of evidence); One Lot Emerald Cut Stones v. United States, 409 U.S. 232, 235 (1972) (per curiam) (holding that the United States was not collaterally estopped from initiating a civil forfeiture proceeding against a defendant who had been acquitted of similar criminal charges because of the burden of proof differential).

For commentary on the consideration of acquitted conduct in sentencing proceedings, see Elizabeth T. Lear, Is Conviction Irrelevant?, 40 UCLA L. REV. $1179,1222-37$ (1993) (arguing that a valid conviction is a constitutionally required prerequisite to imposition of punishment for an offense); Kevin R. Reitz, Sentencing Facts: Travesties of Real-Offense Sentencing, 45 STAN. L. REV. 523, 546-47 (1993) (suggesting that the Supreme Court would easily uphold the constitutionality of using acquitted conduct in sentencing proceedings by resorting to the same arguments made in Dowling $v$. United States "to treat facts as sentencing factors rather than offense elements"); William J. Kirchner, Note, Punishment Despite Acquittal: An Unconstitutional Aspect of the Federal Sentencing Guidelines?, 34 ARIZ. L. REV. 799, 819 \& n.204 (1992) (distinguishing Dowling v. United States from sentencing proceedings because the former context does not involve an attempt to relitigate settled facts in order to impose criminal punishment, as the latter does). For a general discussion of the use of acquitted conduct under the Federal Sentencing Guidelines, see id.

184337 U.S. 241 (1949). Williams involved a convicted murderer who was sentenced to death by the trial judge, despite a jury's recommendation for life. See id. at 242. The trial judge disregarded the jury's recommendation on the basis of a pre-sentencing report that attributed 30 burglaries to the defendant, none of which had been charged. See id. at 244. Furthermore, statements in the report convinced the judge that the defendant had a "morbid sexuality" and was a "menace to society." Id. The defendant challenged his death sentence as a violation of due process, arguing that he was not given an opportunity to confront the witnesses who testified against him in the pre-sentencing report (which had not been introduced at trial) and to cross-examine them. See id. at 243. 
for the proposition that the prosecution would only need to prove this underlying conduct by a preponderance of the evidence. ${ }^{136}$

The Court in Williams, speaking through Justice Black, upheld the sentence, explaining that although the guilt stage of a criminal proceeding was subject to strict evidentiary constraints, the sentencing stage had enjoyed a long tradition of broad judicial discretion in deciding what kind of information would be considered. See id. at 246. Beyond history, "practical reasons" justified the distinction between trial procedures and sentencing procedures. See id. At trial, the issue is guilt, whereas at sentencing, the issue is an appropriate sentence for the particular offender. In the latter proceeding, the judge needs full information, extending beyond the narrow issue of guilt, to impose a proper sentence, particularly in light of "modern" penological goals emphasizing rehabilitation and individualized punishment, rather than retribution. See id. at 246-47. Assessments of a defendant's potential for rehabilitation would draw upon all aspects of a defendant's life, and thus crossexamination would greatly complicate the proceedings, if not frustrate them altogether. See id. at 250. The Court concluded that the Due Process Clause should not obstruct the states' commendable efforts to impose "enlightened" sentences by restricting sentencing information to only that admissible at trial. See id. at 250-51.

${ }^{135} 477$ U.S. 79 (1986). McMillan involved a Pennsylvania statute that made visible possession of a firearm during the commission of specified felonies a sentencing factor requiring a mandatory minimum sentence of five years. See id. at 81 . Possession of the firearm had to be proven by a preponderance of the evidence at the sentencing proceeding. See id. The Court, speaking through Justice Rehnquist, upheld the statute against a due process challenge. The Court explained that Pennsylvania could specify the offense-related conduct of firearm possession as a sentencing factor, rather than as an element of the offense that would have to be established to a certainty beyond a reasonable doubt. See id. at 85-86. Although the reasonable doubt standard constitutionally required by In re Winship, 397 U.S. 358 (1970), could potentially apply to facts not formally identified as elements of the offense, the Court concluded that this was not such a case because, under Pennsylvania's statute, a finding of visible firearm possession would not increase the maximum penalty of any offense subject to the statute, but would simply limit a judge's discretion to determine the minimum penalty. See id. at 86-88. The Court also concluded that the statute's prescribed burden of proof for establishing this sentencing factor, a preponderance of the evidence, would satisfy due process. See id. at 91. Referring to Williams, the Court observed that sentencing courts had traditionally heard evidence and made findings of fact without any prescribed burden of proof at all. See id.

${ }^{136}$ Williams and McMillan establish the general principle that sentencing courts may consider unconvicted or uncharged criminal conduct (either associated with the present offense or with past, unrelated incidents), without trial procedures (rules of evidence, confrontation and cross-examination, or jury trial), under a preponderance of the evidence burden of proof. See supra notes 134-35.

Although Williams and McMillan remain the generally recognized leading cases on the requirements of due process at sentencing, see, e.g., Susan N. Herman, The Tail That Wagged the Dog: Bifurcated Fact-Finding Under the Federal Sentencing Guidelines and the Limits of Due Process, 66 S. CAL. L. REv. 289, 316, 323 (1992) (noting that both decisions are the most frequently cited decisions by the lower courts regarding due process at sentencing), they have been subjected to substantial criticism, and several commentators assert that the Court is incorrect in relying upon them when operating under the Federal Sentencing Guidelines. See, e.g., Gerald W. Heaney, The Reality of Guidelines Sentencing: No End to Disparity, 28 AM. CRIM. L. REV. 161, 214-20 (1991) 
The Court is also correct in concluding that the introduction of a criminal conviction for drunk driving, which must have been proven beyond a reasonable doubt (as required by In re Winship ${ }^{137}$ ), in lieu of direct proof of the underlying conduct would necessarily satisfy this burden of proof. All the Court has proved, however, is that consideration of the conviction at sentencing does not violate the due process requirement that criminal conduct be established by a preponderance of the evidence.

What the Court has not proved is that consideration of uncounseled misdemeanor convictions at sentencing is constitutionally permissible. If such collateral use violates the Sixth Amendment, the fact that it does not run afoul of the constitutionally required minimum burden of proof is irrelevant. The fact that a conviction has been proven beyond a reasonable doubt is significant only if all other constitutionally required trial procedures have been complied with. However certain a jury may have been of guilt, a felony conviction can be reversed, for example, if the defendant was

(arguing that the decisions are not relevant to the Federal Sentencing Guidelines and that relevant conduct should be charged in the indictment, not proved at sentencing); Herman, supra, at 316-39 (arguing that the decisions were wrongly decided, that they have been undercut by other precedents, and that they are inapplicable to the Federal Sentencing Guidelines' determinate sentencing scheme); Lear, supra note 133, at 1214-22 (arguing that the decisions wrongly remove sentencing factors from due process scrutiny by stripping the defendant of his liberty interest up to the statutory maximum and by granting judges absolute discretion to consider any available information in sentencing); Benjamin E. Rosenberg, Criminal Acts and Sentencing Facts: Two Constitutional Limits on Criminal Sentencing, 23 SETON HALL L. REV. 459, 477-87 (1993) (criticizing McMillan for its vagueness, for its devaluation of the role of the jury, for its abdication of judicial responsibility in constitutional interpretation, and for its threat to liberal notions of proportionality in punishment); Richard Husseini, Comment, The Federal Sentencing Guidelines: Adopting Clear and Convincing Evidence As the Burden of Proof, 57 U. CHI. L. REv. 1387, 1399-1405 (1990) (arguing that McMillan is inapplicable to the Guidelines because it was decided in the context of an indeterminate sentencing scheme); Christine A. Neuharth, Comment, Sentencing Enhancement Through Relevant Conduct: United States v. Galloway and the Implications for Due Process, 27 CREIGHTON L. REV. 809, 844-46 (1994) (arguing that Williams and McMillan do not apply to the Guidelines because they were decided in the context of an indeterminate sentencing scheme); of. Sara S. Beale, Procedural Issues Raised By Guidelines Sentencing: The Constitutional Significance of the "Elements of the Sentence", 35 WM. \& MARY L. REV. 147, 159-60 (1993) (suggesting a "bottom line" approach in which criminal defendants at sentencing should be accorded at least the same procedural protections provided to civil defendants at post-liability damageassessment proceedings, protections that criminal defendants do not currently enjoy).

${ }_{137} 397$ U.S. 358, 364 (1970) ("[T]he Due Process Clause protects the accused against conviction except upon proof beyond a reasonable doubt of every fact necessary to constitute the crime with which he is charged."). 
not appointed counsel, ${ }^{138}$ if his confession was coerced, ${ }^{139}$ or if the prosecution's evidence was obtained in violation of the Fourth Amendment. ${ }^{140}$ Likewise, the Court in Tucker held that the consideration of two uncounseled felony convictions at sentencing was unconstitutional, ${ }^{141}$ even though the convictions had presumably been proven beyond a reasonable doubt. The fact that the uncounseled conviction in Tucker satisfied the minimum burden of proof required by the Due Process Clause did not render the collateral use constitutionally permissible; the collateral use of the uncounseled conviction was unconstitutional because it violated the Sixth Amendment. ${ }^{142}$ Similarly, if the use of Nichols's uncounseled misdemeanor conviction at sentencing also violates the Sixth Amendment, the collateral use will be unconstitutional, regardless of its permissibility under the relaxed standards of due process at sentencing.

\section{B. Sentence Enhancement and Scott}

The next leg of the Court's argument asserts that sentence enhancement is valid under the Sixth Amendment because enhancement does not violate Scott. The Court explained that a natural consequence of Scott is that "an uncounseled conviction valid under Scott may be relied upon to enhance the sentence for a subsequent offense, even though that sentence entails imprisonment." ${ }^{\text {143 }}$ Imprisonment is not problematic because "[e]nhancement statutes ... do not change the penalty imposed for the earlier conviction." 144 Whatever penalty a court imposes on the basis of an uncounseled conviction through the operation of an enhancement statute will not trigger the prohibition in Scott because "repeatoffender laws ... [penalize] only the last offense committed by the defendant. ${ }^{145}$

${ }^{138}$ See Gideon v. Wainwright, 372 U.S. 335, 342-44 (1963).

139 See, e.g., Miranda v. Arizona, 384 U.S. 436, 492, 494-95 (1966) (reversing the convictions of several defendants because evidence had been introduced at their trials of confessions obtained in violation of the Fifth Amendment right against selfincrimination).

${ }^{140}$ See Mapp v. Ohio, 367 U.S. 643, 660 (1961) (reversing the defendant's conviction because the evidence offered at her trial had been obtained in violation of the Fourth Amendment right against unreasonable searches and seizures).

${ }^{1+1}$ See supra notes 85-90 and accompanying text.

142 See United States v. Tucker, 404 U.S. 443, 449 (1972).

113 Nichols v. United States, 114 S. Ct. 1921, 1927 (1994).

144 Id.

${ }^{145}$ Id. (quoting Baldasar v. Illinois, 446 U.S. 222, 232 (1980) (Powell, J., 
The Court's argument thus has two propositions: (1) because recidivist statutes punish the last offense only, imposing imprisonment through a recidivist statute does not violate Scott; and (2) because the enhancement is valid under Scott, enhancing prison sentences on the basis of uncounseled convictions does not violate the Sixth Amendment.

This argument is specious. The Court's argument sounds straightforward because the Court often states the rule in Scott in the shorthand fashion: "[S]o long as no imprisonment [is] actually imposed, the Sixth Amendment right to counsel [does] not obtain." 146 Because no imprisonment was imposed for the uncounseled conviction, but rather only for the subsequent counseled offense, it follows that there was no Sixth Amendment violation. The problem with this reasoning is that "no imprisonment" in Nichols means something very different from "no imprisonment" in Scott. In Scott, the Court was addressing the constitutionality of convicting an uncounseled defendant; if the sentence imposed was a fine or probation, conviction would not violate the Sixth Amendment, but if the sentence was imprisonment, conviction would violate the Sixth Amendment. When the Court asserts in Nichols that the defendant did not receive any imprisonment for the uncounseled conviction, the Court does not mean that he instead received a sentence of a fine or probation. The punishment in Nichols was undeniably imprisonment-two extra years in prison through operation of the Federal Sentencing Guidelines. Rather, what the Court means when it asserts that the defendant does not receive any imprisonment for the uncounseled conviction is that the enhanced imprisonment does not punish the uncounseled conviction at all, but only the subsequent offense.

Thus, what the Court is really arguing in Nichols is that Scott does not apply. If Scott applied, as the dissent in Nichols and two of the concurrences in Baldasar assert, ${ }^{147}$ the enhanced sentence,

dissenting)).

$146 \mathrm{Id}$.

${ }^{117}$ Justice Blackmun explained in his Nichols dissent:

Although it is undeniable that recidivist statutes do not impose a second punishment for the first offense in violation of the Double Jeopardy Clause, it also is undeniable that Nichols' DUI conviction directly resulted in more than two years' imprisonment. ... . [W]e consistently have read the Sixth Amendment to require that courts decrease the risk of unreliability, through the provision of counsel, where a conviction results in imprisonment. That the sentence in Scott was imposed in the first instance and the sentence here 
being imprisonment, would violate Scott. When the Court responds to this argument by asserting that enhanced imprisonment does not violate $S c o t t$, it is really asserting that enhanced imprisonment does not violate Scott because Scott does not apply. The Court makes this argument by relying on Moore $v$. Missouri, ${ }^{148}$ a long-standing precedent developed in the double jeopardy context that severs the connection for legal purposes between the original offense and the enhanced sentence. ${ }^{149}$ What this leaves is a sentence of imprisonment imposed upon a counseled conviction; because Scott only arises in situations involving an uncounseled conviction, it simply does not apply to the situation addressed in Nichols.

The error in the Court's argument should be more apparent now. Returning to the propositions stated above, the first proposition can be clarified: (1) because recidivist statutes punish the last offense only, imposing imprisonment through a recidivist statute does not violate Scott because Scott does not apply. This clarification of the first proposition reveals the premise of the second proposition to be incorrect: the enhancement is not valid under Scott. The error lies in the Court's inference that if the enhanced sentence is not invalid under Scott, it must therefore be valid under Scott; in fact, under the Court's argument, the enhanced sentence is neither valid nor invalid under Scott. Thus, the Court's conclusion in the

was the result of an enhancement statute is a distinction without a constitutional difference.

Id. at 1933 (Blackmun, J., dissenting); see also id. at 1935 n.4 (Blackmun, J., dissenting) (stating, in response to Justice Souter's concurrence, "I find the district court's authority to depart downward too tenuous a check on the use of unreliable misdemeanor convictions to salvage a sentencing scheme that is, in my view, a violation of Scott $t^{n}$.

Justice Stewart explained in his Baldasar concurrence that:

In this case the indigent petitioner . . . was sentenced to an increased term of imprisonment only because he had been convicted in a previous prosecution in which he had not had the assistance of appointed counsel in his defense.

It seems clear to me that this prison sentence violated the constitutional rule of Scott $v$. Illinois ....

Baldasar, 446 U.S. at 224 (Stewart, J., concurring). Likewise, Justice Marshall explained in his Baldasar concurrence that "[t]he sentence petitioner actually received would not have been authorized by statute but for the previous conviction. It was imposed as a direct consequence of that uncounseled conviction and is therefore forbidden under Scott and Argersinger." Id. at 227 (Marshall, J., concurring). The defendant in Baldasar also argued that the enhancement violated Scott. See id. at 23132.

148159 U.S. 673 (1895).

${ }^{149}$ See supra note 117. 
second proposition-that enhancing prison sentences on the basis of uncounseled convictions does not violate the Sixth Amendmentdoes not follow from the first proposition. In other words, the Court cannot resolve the issue in Nichols by relying on a rule from a case that does not apply; it must look beyond Scott to determine the constitutionality of enhanced prison sentencing on the basis of uncounseled convictions.

If Scott does not apply, however, as the Court argues, does any Sixth Amendment issue remain to be resolved? After all, the original uncounseled conviction did not violate the Sixth Amendment because it was valid under Scott, and the more recent conviction did not violate the Sixth Amendment because the defendant had counsel. If Moore severs the connection between the uncounseled conviction and the enhanced portion of the sentence of the uncounseled conviction, then what possible violation could be left?

Perhaps this reasoning might be the end of the matter, except that this resolution is hard to reconcile with Burgett and Tucker. In both of these cases, the Court was unwilling to sever the connection between an uncounseled conviction and enhancement in a subsequent offense, even though the same long-standing double jeopardy precedents relied upon in Nichols were also in existence when these cases were decided. Of course, one might point out that in Burgett and Tucker, the original convictions were constitutionally invalid, whereas in Nichols, the original conviction was constitutionally valid. This might be a fair objection if Burgett and Tucker were decided upon the basis of constitutional validity or invalidity. Indeed, the dissent in Baldasar argued that Burgett and Tucker were decided upon this basis, and the majority in Nichols endorsed this view. A closer look at Burgett and Tucker reveals this view to be incorrect.

\section{The Burgett Principle and Constitutional Validity}

The final reason that the Court offered to support the decision in Nichols is that the sentence enhancement in Nichols is distinguishable from the sentence enhancement in Tucker because the uncounseled conviction in Nichols is constitutionally valid. The Court stated that it "agree[d] with the dissent in Baldasar that a logical consequence of [Scott] is that an uncounseled conviction valid under Scott may be relied upon to enhance the sentence for a 
subsequent offense." 150 Justice Powell, in turn, had argued in his Baldasar dissent that "[1]ogically, just as a constitutionally invalid felony judgment could not be used for sentence enhancement in Burgett, the valid misdemeanor conviction in this case should be available to enhance petitioner's sentence."151 Justice Powell explained that the governing principle in Burgett and its progeny was that collateral use must be prohibited "because an uncounseled felony conviction [is] constitutionally invalid-and therefore void. ${ }^{n 152}$

Before Baldasar and Nichols, the Supreme Court had addressed the collateral use of uncounseled convictions in four cases: Burgett v. Tucker, ${ }^{153}$ United States v. Tucker, ${ }^{154}$ Loper v. Beto, ${ }^{155}$ and Lewis

${ }^{150}$ Nichols, 114 S. Ct. at 1927.

151 Baldasar, 446 U.S. at 233 (Powell, J., dissenting).

152 Id. at 232 (Powell, J., dissenting). Justice Powell's approach becomes clearer in several of the footnotes he provided in Baldasar. Under his approach, the validity or invalidity of a conviction translates directly and conclusively into a corresponding validity or invalidity for purposes of collateral use. In response to Baldasar's argument that uncounseled convictions are too unreliable to support sentence enhancement, Justice Powell stated that "[c]ompared to a felony judgment, . . . most uncounseled misdemeanor convictions are far more likely to be reliable. . . . But there is a more fundamental answer to petitioner's argument. Here, the uncounseled conviction is conceded to be valid and thus must be presumed reliable." Id. at 233 n.2 (Powell, J., dissenting).

Justice Powell's approach becomes even more evident in his discussion of Lewis v. United States, 445 U.S. 55 (1980). For a discussion of Lewis, see infra notes 163-67 and accompanying text. Justice Powell compared Lewis to Baldasar in his Baldasar dissent, stating:

Today's decision is all the more puzzling in view of the Court's recent ruling in Lewis v. United States.... Lewis held that even though the federal firearm statute imposes a prison sentence solely because the defendant had an uncounseled-and thus void-felony conviction on his record, that procedure does not use the void conviction to "support guilt or enhance punishment." ... In this case, the Court refuses to permit sentence enhancement on the basis of a constitutionally valid misdemeanor conviction. The conflict between the two holdings could scarcely be more violent.

Baldasar, 446 U.S. at 234 n.3 (Powell, J., dissenting) (citations omitted). For Justice Powell, the constitutional label does all the work. Because uncounseled felony convictions are invalid, they should not have been used in Lewis, and because uncounseled misdemeanor convictions are valid under Scott, they should have been used in Baldasar. If an invalid conviction could be used in Lewis, this reasoning runs, then surely a valid conviction could be used in Baldasar; by deeming the valid conviction invalid for enhancement, the Baldasar decision appeared inconsistent with Lewis.

$$
\begin{aligned}
& 153389 \text { U.S. } 109 \text { (1967). } \\
& 154404 \text { U.S. } 443 \text { (1972). } \\
& { }^{155} 405 \text { U.S. } 473 \text { (1972). }
\end{aligned}
$$


ข. United States. ${ }^{156}$ All four cases involved uncounseled felony convictions, but only three prohibited collateral use. ${ }^{157}$ The fourth case, Lewis, permitted the use of an invalid conviction to bring a defendant within the scope of a federal firearms disability statute, a statute that barred convicted felons from possessing guns and that was enforceable with criminal sanctions. ${ }^{158}$

Lewis raises the question whether the constitutional validity of an uncounseled conviction is actually the governing criteria under Burgett, as the Court in Nichols asserts. Of course, Lewis might be explained as a rejection of Burgett and Tucker. The defendant in Lewis was convicted because he carried a firearm as a convicted felon. ${ }^{159}$ The defendant's only felony conviction was invalid under Gideon. ${ }^{160}$ Thus, Lewis appears flatly inconsistent with Burgett and Tucker: a conviction invalid under Gideon was used to support guilt for another offense. ${ }^{161}$ The Court in Lewis, however, reaffirmed its commitment to Burgett and Tucker and claimed that its decision was completely consistent with those decisions. ${ }^{162}$ In light of this claim, it makes sense to search for a rationale that can explain the result in all of the cases.

That rationale can be seen most conspicuously in Lewis itself, in which the Court emphasized the distinction between collateral uses that depend on the reliability of the prior conviction and those that do not. The Court explained that the Sixth Amendment prohibits the use of uncounseled convictions for some, but not all purposes. ${ }^{163}$ In Burgett, Tucker, and Loper, "the subsequent conviction

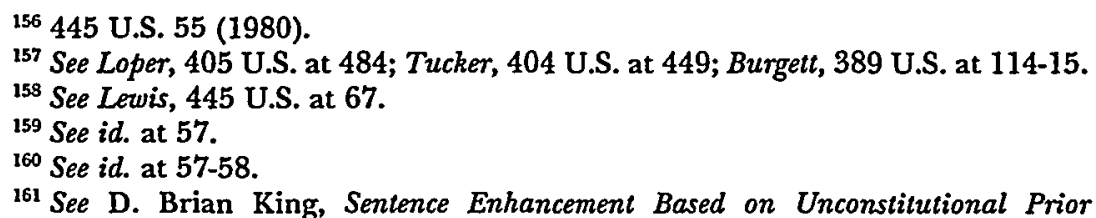
Convictions, 64 N.Y.U. L. REV. 1373, 1386 (1989) ("The Supreme Court's holding in Lewis seems inconsistent with Burgett and Tucker in that it allows a conviction violative of Gideon to be used as the predicate for conviction and imprisonment."); Note, Sixth Amendment Limits on Collateral Uses of Uncounseled Convictions, 91 YALE L.J. 1000, 1006 \& n.45 (1982) ("Lewis's prior conviction was obtained in violation of Gideon, was necessary to establish his guilt under the gun law, and resulted in his punishment for a gun-law offense. This result is in direct contravention of a statement made in Burgett that 'a conviction obtained in violation of Gideon $v$. Wainwright [cannot] be used against a person to support guilt or enhance punishment for another offense ....' (quoting Burgett, 389 U.S. at 115) (alteration in original)).

${ }^{162}$ See Lewis, 445 U.S. at 66-67. Moreover, the Court has continued to adhere to Burgell and Tucker. See Nichols v. United States, 114 S. Ct. 1921, 1925 n.9 (1994); Custis v. United States, 114 S. Ct. 1732, 1738-39 (1994).

${ }^{169}$ See Lewis, 445 U.S. at 66-67. 
or sentence violated the Sixth Amendment because it depended upon the reliability of a past uncounseled conviction. ${ }^{n 164}$ When the purpose for using the prior conviction does not depend on the reliability of the conviction, however, the Sixth Amendment does not prohibit its collateral use. Under the firearms disability statute at issue in Lewis, Congress's purpose was to keep guns out of the hands of potentially dangerous individuals. ${ }^{165}$ Congress determined that any person convicted of, or even indicted for, a felony offense was a potentially dangerous individual, and the Court in Lewis concluded that Congress's judgment was rational. ${ }^{166}$ This collateral use did not depend upon the reliability of the prior conviction, given the fact that even an indictment was sufficient to trigger the firearm disability, but rather depended only upon the fact of conviction itself. ${ }^{167}$ Because the reliability of the prior conviction did not matter in this collateral use, the fact that it was uncounseled and thus unreliable presented no constitutional obstacle to its use.

Lewis demonstrates that the analysis under Burgett is more principled and less mechanical than that suggested by the Court in Nichols. The proper inquiry is not simply whether the conviction is constitutionally valid or invalid, but rather whether the defect in the prior conviction (the reason the conviction is invalid) makes the proposed collateral use unconstitutional as well. Although less explicit than in Lewis, this principle can also be seen at work in Burgett, Tucker, and Loper. In Burgett, evidence of prior uncounseled felony convictions was introduced at trial pursuant to a recidivist statute. ${ }^{168}$ The trial judge later determined that the prosecution could not meet its burden under the recidivist statute and instructed the jury to disregard the convictions. ${ }^{169}$ The jury instructions notwithstanding, the Court reversed the conviction because it feared that the jury improperly determined guilt on the basis of the prior convictions. ${ }^{170}$ In Tucker, the trial judge took the defendant's prior felony convictions into account when determining the defendant's sentence. ${ }^{171}$ When two of the prior convictions were

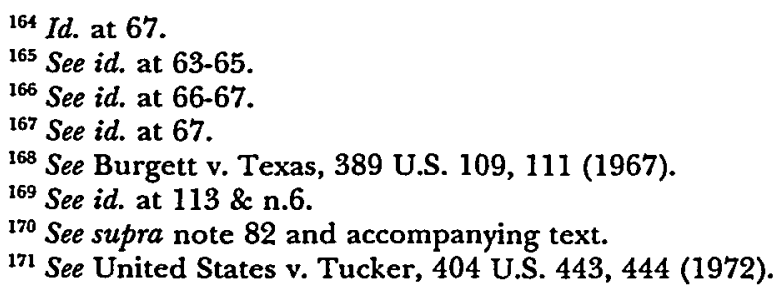


later shown to be invalid under Gideon, the Court required the judge to resentence the defendant without any consideration of the invalid convictions. ${ }^{172}$ In Loper, evidence of prior uncounseled convictions was introduced at trial to impeach the testimony of the defendant. ${ }^{173}$ Noting that the case essentially amounted to the defendant's word against the victim's, the Court reversed the conviction because the prosecution's attack on the defendant's credibility was intended to prove guilt. ${ }^{174}$

In each case, the Court explained that the proposed collateral use, whether supporting guilt (Burgett, ${ }^{175}$ Loper $^{176}$ ) or enhancing punishment (Tucker ${ }^{177}$ ), would erode the principle of Gideon. ${ }^{178}$ The basic principle of Gideon is that guilt determinations are too unreliable in the absence of counsel to tolerate criminal conviction and sanction. The implicit chain of reasoning in Burgett, Tucker, and Loper, then, is that when an uncounseled conviction is introduced in a collateral proceeding to prove that the defendant has committed a crime before, that conviction is every bit as unreliable as the guilt determination made in the original prosecution. If the defendant could avoid criminal sanctions for the imputed criminal conduct that this unreliable guilt determination represents only in the initial proceeding, but not in collateral proceedings, then the principle of Gideon would indeed be eroded. There would then exist a category of criminal prosecutions in which criminal sanctions would be tolerated even though the criminal conduct upon which

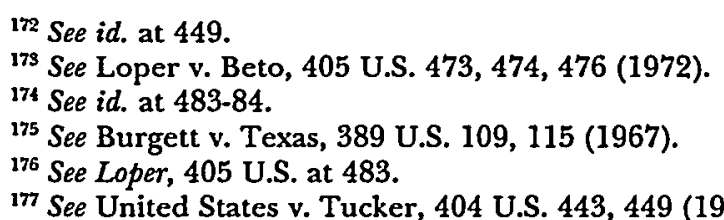

177 See United States v. Tucker, 404 U.S. 443, 449 (1972).

${ }^{178}$ Although Burgett, Tucker, Loper, and Lewis all involved the collateral use of convictions that were obtained in violation of the right to counsel, the principle in Burgett may apply to the collateral use of convictions obtained in violation of other constitutional guarantees as well. The Supreme Court has not addressed this question directly, but it has suggested in dicta that the principle may indeed apply to other constitutional violations. In Zant v. Stevens, 462 U.S. 862 (1983), the Court stated that "[a]s we held in United States $v$. Tucker, . . . the sentence must be set aside if the trial court relied at least in part on 'misinformation of constitutional magnitude' such as prior uncounseled convictions that were unconstitutionally imposed." Id. at $887 \mathrm{n} .23$ (citation omitted). The use of the words "such as" suggests that convictions invalid on other grounds may also be invalid for collateral use. See King, supra note 161 , at 1387 n.112. Many of the federal courts of appeals have extended Tucker to other constitutional violations, including ineffective assistance of counsel, involuntary guilty pleas, violations of the Fifth Amendment right against self-incrimination, and violations of the Fourth Amendment. See id. at 1389, 1393. 
the sanctions are imposed was determined in the absence of counsel. The Sixth Amendment would protect defendants from the direct consequences of unreliable fact-finding, but not the collateral consequences of such fact-finding.

What does this mean for Nichols? If Burgett and its progeny are properly understood as an extension of the Gideon principle to the collateral use of convictions, then the sentence enhancement in Nichols must still be subject to a Sixth Amendment check. Although constitutionally valid, the prior conviction was uncounseled, and reliability is still a concern under Scott and Argersinger. Furthermore, the collateral use at issue-sentence enhancement-depends on the reliability of the prior conviction. Thus, the sentence enhancement in Nichols is still governed by the principles in Burgett and Tucker, even though the prior conviction was constitutionally valid under Scott.

\section{Alternative Resolutions UNDER THE SiXTh AMENDMENT}

Two conclusions emerge from the foregoing analysis. First, the Court has not offered any valid rationale for upholding sentence enhancement under the Sixth Amendment. The Court cannot uphold enhancement by asserting that enhancement does not violate $S$ cott because, by its own reasoning, Scott does not apply. At best, this argument can deny only one possible Sixth Amendment objection to the constitutional validity of enhancement. Nor can the Court distinguish Tucker by relying on the constitutional validity of the uncounseled misdemeanor conviction because the triggering condition in Tucker was the absence of counsel in the prior conviction, not the formal constitutional validity or invalidity of the conviction. Finally, the Court's due process argument is simply an irrelevant truism.

The second conclusion is that a Sixth Amendment question remains to be resolved in Nichols. Under the rationale of Burgett and Tucker, sentence enhancement, even enhancement based upon an uncounseled conviction that is constitutionally valid, must be subject to scrutiny under the Sixth Amendment because the conviction's reliability is questionable $e^{179}$ and sentence enhance-

${ }^{179}$ The Court has never rejected its conclusion in Argersinger that uncounseled misdemeanor convictions are no more reliable than uncounseled felony convictions. See supra notes 53-67 and accompanying text. 
ment is a collateral use that depends on the reliability of the enhancement-triggering conviction. ${ }^{180}$

Justice Souter suggested in concurrence that sentence enhancement under the Federal Sentencing Guidelines does satisfy the Sixth Amendment's concern for reliability. This Part will first examine Justice Souter's opinion to determine whether it applies the appropriate Sixth Amendment scrutiny as required by the rationale in Burgett and Tucker. This Part will then examine an extension of Justice Blackmun's argument in dissent and suggest a different analysis that may arrive at a similar result.

\section{A. Justice Souter's Concurrence: A Revival of Betts v. Brady}

Justice Souter concurred in the judgment, but wrote separately from the majority because he thought the case was properly decided on the narrow facts of the Federal Sentencing Guidelines. ${ }^{181}$ Justice Souter acknowledged that there was "an obvious and serious argument" that enhancing sentences on the basis of uncounseled misdemeanor convictions violates $S \operatorname{cott},{ }^{182}$ but he thought that the Court did not have to answer that question because the Sentencing Guidelines were distinguishable from the automatic sentencing scheme considered in Baldasar. ${ }^{183}$ The distinguishing feature of the Guidelines was that they permit sentencing judges to depart from the applicable sentencing range and impose a shorter sentence if the defendant's criminal history category "'significantly overrepresents the seriousness of a defendant's criminal history or the likelihood that the defendant will commit further crimes." 184 The Guidelines gave the defendant a chance to persuade the sentencing judge that prior convictions were unreliable because they were obtained without counsel. ${ }^{185}$ A defendant could argue that "his

${ }^{180}$ See Lewis v. United States, 445 U.S. 55, 67 (1980) (explaining that the collateral use of an uncounseled conviction for sentence enhancement in Tucker "depended upon the reliability" of that conviction).

${ }^{181}$ See Nichols v. United States, 114 S. Ct. 1921, 1931 (1994) (Souter, J., concurring) ("I am shy . . . of endorsing language in the Court's opinion that may be taken as addressing the constitutional validity of a sentencing scheme that automatically requires enhancement for prior uncounseled convictions, a scheme not now before us.").

${ }^{182} I d$. at 1929 (Souter, J., concurring).

${ }^{\text {t8s }}$ See id. at 1930 (Souter, J., concurring).

${ }^{184}$ Id. (Souter, J., concurring) (quoting U.S. SENTENCING GUIDELINES, GuIDELINES MANUAL § 4A1.3 (1993)).

${ }^{185}$ See id. (Souter, J., concurring). 
prior conviction resulted from railroading an unsophisticated indigent, from a frugal preference for a low fine with no counsel fee, or from a desire to put the matter behind him instead of investing the time to fight the charges. ${ }^{186}$ Because the defendant has this opportunity to demonstrate that prior convictions are unreliable, the Guidelines "do not ignore the risk of unreliability associated with such a conviction," 187 and "[w]here concern for reliability is accommodated, as it is under the Sentencing Guidelines, nothing in the Sixth Amendment or our cases requires a sentencing court to ignore the fact of a valid uncounseled conviction." 188

Under Justice Souter's approach, uncounseled convictions may be considered at sentencing under recidivist statutes as long as the sentencing judge has discretion to disregard the conviction if the judge believes the conviction to be unreliable. This approach raises several questions. First, Justice Souter does not explain why discretionary sentencing schemes avoid the "serious argument" faced by automatic sentencing schemes that enhancement violates Scott. If the judge remains unconvinced, then the argument in Baldasar that enhancement violates Scott would seem to apply to discretionary sentencing schemes as well: in both cases, the defendant is sentenced to an increased sentence only because the defendant was previously convicted in a prosecution in which he did not have the assistance of counsel.

Second, Justice Souter asserts that this judicial discretion accommodates the Sixth Amendment's concern for reliability, but his assertion begs the question, is this discretion sufficient? Justice Souter jumps from the proposition that the Guidelines do not "ignore the risk of unreliability" associated with uncounseled convictions (because sentencing judges are not always required to enhance the sentence as they would be under an automatic sentencing scheme) to the proposition that the Guidelines sufficiently accommodate the Sixth Amendment's reliability concerns. ${ }^{189}$ This is a big jump for which Justice Souter offers no support. The approach Souter proposes-case-by-case judicial review of reliability after the determination of guilt-is the approach

${ }^{186} I d$. (Souter, J., concurring).

${ }^{187} \mathrm{Id}$. (Souter, J., concurring).

${ }^{188} \mathrm{Id}$. (Souter, J., concurring).

${ }^{189}$ See id. at $1929-30$ (Souter, J., concurring). 
that Betts v. Brady ${ }^{190}$ represented and the approach that Gideon rejected when it overruled Betts. ${ }^{191}$

Before Gideon, the right to counsel was governed by Betts, which required courts to determine on a case-by-case basis whether the lack of counsel in a particular trial violated the Due Process Clause's guarantee of "fundamental fairness." 192 This "special circumstances" rule was gradually eroded over the next twenty years, as the Court continually expanded the scope of the "special circumstances" by requiring the aid of counsel to result in a fair trial. ${ }^{193}$ The Court finally abandoned the Betts rule in Gideon, concluding that no defendant could be assured a fair trial without the right to counsel. ${ }^{194}$

Professor Yale Kamisar wrote a series of law review articles during this period, explaining the problems with the Betts rule. Under Betts, courts were evaluating claims by examining trial records for evidence that the defendant was disadvantaged by the absence of counsel. Professor Kamisar objected to this process, stating:

What do[es it] mean [to say that a record can] "establish that the defendant was not disadvantaged by the absence of counsel?" A record can "establish" no such thing. It can only fail to establish on its face that the defendant was disadvantaged. What does it prove that the record reads well? How would it have read if the defendant had had counsel? What defenses would have been

190316 U.S. 455 (1942).

191 See Gideon v. Wainwright, 372 U.S. 335, 339 (1963).

192 See Betts, 316 U.S. at 473.

${ }^{193}$ See Gideon, 372 U.S. at 350-51 (Harlan, J., concurring). Justice Harlan stated that part of the reason he joined the Court's unanimous decision was because the Betts rule was "no longer a reality." Id. at 351 (Harlan, J., concurring). Justice Harlan explained:

In the first decade after Betts, there were cases in which the Court found special circumstances to be lacking, but usually by a sharply divided vote. However, no such decision has been cited to us, and I have found none, after ... 1950. At the same time, there have been not a few cases in which special circumstances were found in little or nothing more than the 'complexity' of the legal questions presented, although those questions were often of only routine difficulty. The Court has come to recognize, in other words, that the mere existence of a serious criminal charge constituted in itself special circumstances requiring the services of counsel at trial.

Id. at 350-51 (Harlan, J., concurring) (citation omitted) (footnotes omitted). ${ }^{194}$ See id. at $342-44$. 
raised then which are not suggested now? We don't know and we never will. This is the main point, the one Betts misses. ${ }^{195}$

Of course, some uncounseled defendants would be convicted even with the aid of an attorney. The point that Professor Kamisar was making is that determining reliability after the fact will create too many false negatives. Frequently, defendants with valid defenses will be too unaware or too incompetent to raise them, leaving a barren record that makes the defendant look overwhelmingly guilty.

By asserting that judicial discretion at sentencing properly accommodates the Sixth Amendment's reliability concern, Justice Souter is essentially reviving the Betts rule in the context of sentence-enhancement proceedings. Not only was this approach rejected in Gideon, but it implicates the same problems that Professor Kamisar highlighted with regard to judicial review of convictions during the Betts era. Although the defendant or the defendant's attorney may enjoy the opportunity to persuade a sentencing judge that prior misdemeanor convictions should not be used under the applicable sentence-enhancement statute because the convictions were uncounseled, the defendant often will have difficulty convincing the judge that counsel would have made any difference. Every time a judge considers using an uncounseled

195 Yale Kamisar, The Right to Counsel and the Fourteenth Amendment: A Dialogue on "The Most Pervasive Right" of an Accused, 30 U. CHI. L. REV. 1, 53 (1962). More recently, Kamisar again explained the problems with the Betts rule:

Its greatest weakness-its most frustrating feature-is that the likely adverse consequences of deprivation of counsel served as the justification for the deprivation.

On rare occasions, a record may contain egregious errors that leap out at any objective observer and demonstrate that an unrepresented defendant did not get a fair trial. But a bare record can never establish that the unrepresented did get a fair trial. . . . A record produced without the input of a defense lawyer does not and cannot reflect what defenses and mitigating circumstances a trained advocate would have seen or what lines of inquiry she would have pursued or what evidence or witnesses a competent pretrial investigation would have turned up.

But the failure of the unrepresented defendant to develop a satisfactory theory or, if he does, to support it with adequate evidence-likely consequences of being without the aid of counsel inside and outside the courtroom-makes the case seem exceedingly simple and the defendant look overwhelmingly guilty. The lack of defense counsel often makes it appear that no lawyer could have saved the defendant anyway and thus the lack of counsel often serves as justification for the lack of counsel.

Yale Kamisar, Gideon v. Wainwright a Quarter-Century Later, 10 PACE L. REv. 343, 349-50 (1990). 
conviction to enhance the sentence of a later conviction, the judge will likely hear the same story, often repeated by the same public defenders, about what a travesty of justice it was that this poor defendant was convicted by overreaching prosecutors. Meanwhile, the judge will be staring at old trial transcripts or (much more frequently) records of guilty pleas, often for multiple prior convictions, and only rarely finding anything with which to question the defendant's guilt.

Thus, in endorsing judicial discretion, Justice Souter embraces an approach that poses serious practical difficulties and that has long since been discredited by the Court's precedents. Not only does Justice Souter's approach appear problematic in that it does not adequately accommodate the Sixth Amendment's reliability concerns, but it also appears problematic in that it focuses only on reliability concerns. At this point in the Court's Sixth Amendment jurisprudence, the defendant should not have to argue that uncounseled convictions are unreliable. In Gideon, the Court declared that uncounseled convictions should be uniformly treated as unreliable, and in Argersinger, the Court made clear that misdemeanors, too, should be treated as unreliable. Although the Court upheld uncounseled convictions not resulting in prison sentences in Scott, the Court's decision was not based on a rationale that misdemeanor convictions not resulting in prison sentences are more reliable than those that do. Rather, the Court decided that the cost of requiring defense counsel for all offenses authorizing imprisonment outweighed the cost of letting defendants suffer nonimprisonment misdemeanor penalties. That the constitutionality of an uncounseled misdemeanor conviction hinges on the sentence imposed after the conviction, and thus after the reliability is already fixed, shows that reliability is not the only factor at work in the Court's contemporary Sixth Amendment doctrine.

By concentrating solely on reliability and suggesting that each defendant must prove each prior uncounseled conviction unreliable before a particular judge at sentencing, Justice Souter takes the Court's Sixth Amendment jurisprudence back fifty years. By suggesting that reliability is the only relevant concern, Souter ignores Argersinger and Scott; and by suggesting that the defendant should have to prove each particular conviction unreliable on a caseby-case basis, Souter ignores Gideon. 


\section{B. Evaluating the Validity of Collateral Sentence Enhancement Under the Court's Sixth Amendment Jurisprudence}

If the reasons offered by the majority and by Justice Souter do not provide a satisfactory resolution under the Sixth Amendment, how, then, should the Court have resolved the issue? One could argue, as Justice Blackmun did in dissent, that the court was simply wrong in asserting that Scott did not apply to sentence enhancement. ${ }^{196}$ One could develop this argument by asserting that the Court erred in relying on Moore $v$. Missouri ${ }^{197}$ and similar precedents that attribute the enhanced portion of a sentence to the current offense rather than the prior offense that served as the authorizing condition for the enhancement. This argument would not deny the validity of these precedents but rather would deny that they are applicable in this context. These precedents, after all, were decided in the face of challenges to the constitutional validity of recidivist statutes, ${ }^{198}$ rather than challenges to the use of a particular defective conviction under these recidivist statutes. Recidivist statutes were challenged, for example, as impermissibly punishing a defendant a second time for the original offense in violation of the Double Jeopardy Clause, ${ }^{199}$ or as a violation of the Ex Post Facto Clause when applied to convictions imposed before the statutes were enacted. ${ }^{200}$ It was in response to these and similar challenges that would render all recidivist statutes unconstitutional that the Court decided to characterize enhancement as punishment solely for the current offense.

The Court has not resorted to this characterization, however, when the context is a constitutional challenge to the use of a particular conviction under a recidivist statute. Thus, in Tucker, the Court prohibited the consideration of uncounseled convictions at sentencing, despite the existence of these precedents at that time. The Court in Tucker could have relied on Moore to assert that the enhanced sentence punished the defendant solely for the last offense, a prosecution in which the defendant did have counsel, and thus that the consideration of the prior uncounseled conviction did not violate the Sixth Amendment. It did not. The Court did not mention Moore or any of the other precedents, nor did it give any

\footnotetext{
196 See supra note 147.

197159 U.S. 673 (1895).

198 See supra notes 25-30 and accompanying text.

${ }^{199}$ See supra note 25.

${ }^{200}$ See supra note 28.
} 
indication that it intended to reject Moore or that it believed Moore was no longer valid law. Apparently, this argument would assert, the Court did not find Moore applicable to this context. Comparing Tucker to Moore, then, reveals that the Court is not particularly interested in the metaphysical relationship between an enhanced sentence and the current and prior offenses that in combination trigger the enhanced sentence, but rather that the Court is concerned about policy. ${ }^{201}$ The Court characterizes the relationship in one way when the policy is permitting states to supplement their criminal law with recidivist statutes and in another way when the policy is protecting the constitutional rights of criminal defendants. Thus, in Nichols, where the policy was protecting constitutional rights, the Tucker characterization was appropriate, not the Moore characterization applied by the majority. This argument would then conclude by asserting that, because the enhancement does punish the defendant for the prior uncounseled conviction, and because this enhancement takes the form of incarceration, the enhancement violates $S$ cott.

Although this argument seems preferable to the majority's in that it distinguishes between the characterizations of sentence enhancement in Tucker and Moore, it shares the majority's overly mechanical interpretation of Scott. Both sides of the debate treat Scott as simply a command not to impose imprisonment for an uncounseled conviction, ${ }^{202}$ with the point of disagreement center-

${ }^{201}$ Professor Lear argues that the Court's characterization of sentence enhancement was motivated by policy concerns. She states:

The Court assumed that if it acknowledged that the prior offense was indeed punished by the harsher penalty at sentencing a double jeopardy violation would automatically follow. Because such a result was both intuitively and politically unpalatable, the Court simply avoided the double jeopardy question altogether by refusing to accept the punishment description.

Elizabeth T. Lear, Double Jeopardy, The Federal Sentencing Guidelines, and the SubsequentProsecution Dilemma, 60 BROOR. L. REV. 725, $741-42$ (1994). Professor Lear further argues that this characterization was unnecessary because a second punishment for the prior conviction would not violate the Double Jeopardy Clause. See id. at 742. She urges the Court to abandon the rationale in Moore altogether because its "fictional view of punishment" currently justifies enhancements for unadjudicated criminal conduct, a practice she asserts is unconstitutional under the Due Process Clause. See id. at 747-48, 758.

${ }^{202}$ See Nichols v. United States, 114 S. Ct. 1921, 1931 (1994) (Blackmun, J., dissenting) (stating that "one principle [in the Court's Sixth Amendment jurisprudence] has been clear, at least until today: no imprisonment may be imposed on the basis of an uncounseled conviction"); supra note 146 and accompanying text. 
ing on whether enhancing a sentence imposes imprisonment for the prior uncounseled conviction. The result in Scott was not decided in the abstract, however, but rather in the face of a claim that the Sixth Amendment required appointed counsel for all defendants charged with a misdemeanor offense authorizing imprisonment. ${ }^{203}$ In this context, the Court decided that the burden to the states (appointing counsel for all misdemeanors authorizing imprisonment or foregoing enforcement of those crimes altogether with regard to indigent defendants) outweighed the consequences of conviction to the defendant (criminal fines or probation). ${ }^{204}$ On the other hand, when incarceration was imposed, the consequences of conviction outweighed the burden to the states (appointing counsel to only those misdemeanor offenses in which imprisonment is actually imposed, rather than the much larger number that authorize imprisonment). ${ }^{205}$ In the latter case, not only was the consequence to the defendant greater, but the burden to the states was smaller. As the consequences and burdens change, so too does the constitutionality of convicting defendants without counsel.

This balance between the consequences of conviction and governmental burden takes a different form in the context of sentence enhancement than in the context of direct sentencing. Thus, it would be inappropriate to apply the Scott prohibition to the sentence enhancement in Nichols without any independent determination of whether the result is also justified in the Nichols context. Presumably, this independent determination would weigh the consequences to the defendant of an additional term of imprisonment against the burden to the states of prohibiting enhancements for valid uncounseled convictions. ${ }^{206}$

${ }^{203}$ See Scott v. Illinois, 440 U.S. 367,368 (1979).

${ }^{204}$ See supra notes 61-74 and accompanying text.

${ }^{205}$ See supra notes 61-74 and accompanying text.

${ }^{206}$ Reliability does not play a prominent role in this determination because Argersinger and Scott shifted the analysis to the competing demands of criminal defendants and the states in misdemeanor prosecutions. Argersinger established the proposition that uncounseled misdemeanor convictions are unreliable. See supra notes 53-59 and accompanying text. The valid uncounseled convictions at issue here are just as unreliable as the misdemeanor convictions deemed invalid under Argersinger; the fact that the constitutionality of any misdemeanor conviction cannot be determined until the sentence is imposed, which necessarily comes after the conviction and the reliability of the factfinder's guilt determination has already been fixed, demonstrates that the constitutional analysis turns on factors other than reliability. Those factors are the relative burdens to the defendant and to the state of permitting or prohibiting the use of the uncounseled conviction. See supra notes 53-74 and accompanying text. 
As for the consequences to the defendant, the enhanced imprisonment may not be quite as severe as a sentence of imprisonment imposed directly. Although the enhancement of a seventeenyear sentence by two years may seem no different from the direct imposition of a two-year sentence in terms of the length of time one is deprived of liberty, the two sentences are different if conviction and imprisonment also entail social stigma. ${ }^{207}$ If a stigma attaches to the judgment that one deserves to go to jail (which would explain the difference in social attitudes toward an individual who sits in jail for six months before trial because of an inability to pay for bail and a convicted defendant who serves a six-month jail sentence), then enhancing a sentence would increase the length of a defendant's liberty deprivation. But it would not stigmatize the defendant to the same degree that the direct imposition of an equivalent sentence would. $^{208}$ In the case of an enhanced sentence, the stigma of conviction and incarceration is already present. Thus, the enhancement of a seventeen-year sentence by two years, although equivalent in the duration of liberty deprivation, may not be as severe as the direct imposition of a two-year sentence because the direct sentence bears a degree of social stigma that the enhanced sentence does not. ${ }^{209}$ A two-year enhancement, however, is surely more severe

${ }^{207}$ The Court has recognized this aspect of criminal conviction. See, e.g., Ball v. United States, 470 U.S. 856, 864-65 (1985) (explaining that a conviction constituting an impermissible punishment under the Double Jeopardy Clause remains impermissible even if the sentence is served concurrently with a sentence for a different conviction because the defendant still suffers adverse consequences from the conviction, including the "societal stigma accompanying any criminal conviction"); In re Winship, 397 U.S. 358, 363 (1970) ("The accused during a criminal prosecution has at stake interests of immense importance, both because of the possibility that he may lose his liberty upon conviction and because of the certainty that he would be stigmatized by the conviction.").

${ }^{208}$ One commentator suggests:

It is worse to go from no conviction and hence no prison term to, say, conviction and three years in prison than it is to go from five years in prison to eight years in prison, even though both involve increases of three years. The marginal cost to the defendant is higher in the first example for two primary reasons. First, it includes the stigma of conviction, and the resulting penalties that convictions carry. Second, rational individuals "discount" the future, which means that they value time in the future less than they value time in the present.

Tung Yin, Comment, Not a Rotlen Carrot: Using Charges Dismissed Pursuant to a Plea Agreement in Sentencing Under the Federal Guidelines, 83 CAL. L. REV. 419, 451-52 (1995) (footnotes omitted).

${ }^{209}$ An enhanced sentence may carry some degree of social stigma. The judgment that a defendant deserves 20 years in prison seems more severe intuitively than the judgment that a defendant deserves two years in prison. The comparative severity 
than a $\$ 250$ fine. Moreover, in some cases, the consequences of conviction can be fairly stiff-in Baldasar, a maximum one-year sentence was converted into a maximum three-year sentence. ${ }^{210}$ In the range of consequences, then, sentence enhancement falls among the more severe penalties, if not the most severe.

As for the burden to the states, the prohibition on uncounseled sentence enhancement is not the same as the burden contemplated in Scott. The authorized imprisonment standard contemplated in Scott would force the states to forego enforcement of most misdemeanors unless they were willing to provide counsel. A prohibition on sentence enhancement, like the actual imprisonment standard adopted in Scott, does not force states to forego enforcement of any misdemeanor offense, but rather removes a sentencing option after conviction. How this burden compares to the burden imposed by the actual imprisonment standard remains uncertain. Only a portion of uncounseled defendants will be convicted again, so the removal of the sentencing enhancement option will affect a smaller pool of convictions than removal of the actual imprisonment standard did in Scott. On the other hand, states will probably want to enforce their recidivist statutes whenever the statutes are applicable, ${ }^{211}$ whereas the states generally do not want to enforce their imprisonment sanctions in all, or even most, misdemeanor convictions. ${ }^{212}$

would presumably decrease as the difference in the duration of sentences decreases, but a 19-year sentence could conceivably possess a marginally greater degree of social stigma than a 17-year sentence.

${ }_{210}$ See Baldasar v. Illinois, 446 U.S. 222, 223 (1980).

211 Recidivist statutes often mandate enhancement in all but narrow circumstances. See, e.g., CAL. PENAL CODE $§ 667$ (f)(1)-(2)(West Supp. 1995) (stating that the recidivist statute must be applied in all cases in which the defendant has a prior felony conviction unless the prosecution cannot prove the prior conviction or withdraws the allegation of conviction "in the furtherance of justice"); GA. CODE ANN. § 17-10-7(a) (Supp. 1995) (requiring courts to impose the maximum sentence authorized for the conviction offense if the defendant has served a prison term for a prior felony conviction). Furthermore, as indicated by legislative policy statements, state legislators view rigorous enforcement of state recidivist statutes as an important part of effective crime control. Florida's policy statement is typical:

The Legislature hereby finds that a substantial and disproportionate number of serious crimes is committed in Florida by a relatively small number of multiple and repeat felony offenders, commonly known as career criminals. The Legislature further finds that priority should be given to the investigation, apprehension, and prosecution of career criminals in the use of law enforcement resources and to the incarceration of career criminals in the use of available prison space.

FLA. STAT. ANN. \$ 775.0841 (West 1992).

${ }^{212}$ States will not want to incarcerate the bulk of misdemeanor convicts both 
Thus, the burden to the states imposed by a prohibition on sentence enhancement may not be as great as that contemplated in Scott (appointing counsel to most misdemeanors or foregoing enforcement of them) or even in Argersinger (foregoing the option of imprisonment in misdemeanor prosecutions unless counsel is provided), whereas the consequence of conviction to the defendant may be nearly as severe as that considered in Argersinger (direct imprisonment) and more severe than that considered in Scott (fines or probation). This relative balance might suggest that sentence enhancement should be prohibited under the Sixth Amendment because the consequences resulting from an unreliable conviction outweigh the burden to the state of foregoing the sentenceenhancement option. ${ }^{213}$ A sense of certainty is elusive in this determination, however, because of the difficulties in quantifying the burden to the states and assigning relative values to individual rights. Perhaps the Court cast its decision as basically predetermined by Scott to avoid these difficulties. Or perhaps the current Court believes that this kind of balancing should be undertaken by state legislatures rather than by the federal judiciary. ${ }^{214}$ Whatever

because misdemeanor offenses generally criminalize minor, nonviolent criminal conduct and because the number of misdemeanor defendants far exceeds available jail space. Mandatory sentencing for felony drug and violent offenders, as well as the widespread existence of court-ordered prison caps, further reduces the capacity to incarcerate misdemeanor defendants. See J. Michael Quinlan, Intermediate Punishments As Sentencing Options, 66 S. CAL. L. REv. 217, 218-19 (1992) (noting that federal prisons are operating substantially beyond their designed capacity and attributing this overcrowding in part to the increased use of mandatory minimum sentences and the reduced use of parole); Susan P. Sturm, The Legacy and Future of Corrections Litigation, 142 U. PA. L. REv. 639, 641-42 (1993) ("As of January 1993, forty states plus the District of Columbia, Puerto Rico, and the Virgin Islands were under court order to reduce overcrowding and/or eliminate unconstitutional conditions of confinement. Twenty-five percent of all jails in the United States were under court order to reduce crowding in $1990 \ldots$... (footnote omitted)).

${ }^{213}$ On the other hand, perhaps the burden assumed by the states should be viewed cumulatively; the costs imposed in the form of public defenders and sentencing restrictions may already approach constitutional limits.

${ }^{214}$ The effect of the Court's decision is to do just that, of course: by upholding the collateral sentence enhancement of uncounseled convictions, the Court left to each state the decision whether to prohibit collateral sentence enhancement, whether to appoint counsel to all defendants charged with misdemeanors that trigger enhanced punishment, or whether to do neither and simply adhere to the federal minimum standard.

The decision in Nichols could be explained by the desire to leave state legislatures with the autonomy to allocate social resources between their criminal justice systems and other government services, or it could be explained by any number of other theories that describe Supreme Court decisionmaking on bases other than the 
the possible underlying motivation for the decision, however, the purpose of this Comment is to demonstrate that the Court's written opinion fails to offer a valid rationale for its decision to uphold the collateral sentence enhancement of uncounseled misdemeanor convictions.

Although Nichols appears unlikely to change in the foreseeable future, ${ }^{215}$ examining the soundness of its reasoning is important because of the influence Supreme Court opinions still have on the evolution of state criminal procedure. State constitutional law has enjoyed a revival in recent years, but many states still follow the Supreme Court's decisions closely. ${ }^{216}$ States may adopt Nichols either because they find it persuasive or because they find in the opinion a respectable pretext for achieving a result they like. By pointing out the deficiency in Nichols's reasoning, it is hoped that in the former case, states will examine their own policies and values in deciding the issue, and in the latter case, states will at least arrive at the result forthrightly, bearing full responsibility for the choice they make.

\section{DEVELOPING INDEPENDENT STATE STANDARDS}

The Court in Nichols reminds the states that they "may decide, based on their own constitutions or public policy, that counsel should be available for all indigent defendants charged with misdemeanors." ${ }^{217}$ Another option which the Court does not

doctrinal reasons offered in its written opinions-political convictions, strategic behavior, shifts in dominant judicial philosophies, and voting blocs. See, e.g., William N. Eskridge, Jr. \& Philip P. Frickey, Foreword: Law As Equilibrium, 108 HARV. L. REv. 26, $42-45$ (1994). Eskridge and Frickey state:

Nichols ... illustrates several interesting features of the Court's institutionally strategic behavior. Because Congress and the President have grown increasingly conservative as to the procedural rights of criminal defendants, the Court has substantial freedom to implement its own strongly held conservative preferences, without fear of override. In order to achieve its substantive "law and order" agenda, the Rehnquist Court has compromised the rule-of-law values of stare decisis in Nichols and earlier decisions narrowing criminal procedural rights. These cases exemplify a more general proposition: to the Court, stare decisis considerations are least compelling for prior decisions that expanded constitutional rights, because such decisions cannot easily be overridden in the normal political process.

Id. at 45-46 (footnotes omitted).

${ }^{215}$ Nichols was decided by a six-to-three majority, and the author of the dissenting opinion, Justice Blackmun, has since retired from the Supreme Court.

${ }^{216}$ See infra part VI.

${ }^{217}$ Nichols v. United States, 114 S. Ct. 1921,1928 n.12 (1994). 
mention is that states may bar the use of all uncounseled misdemeanor convictions under recidivist statutes, even those validly obtained under Scott. The states may choose either option, of course, because Nichols, in construing the requirements of the Sixth Amendment, establishes only the minimum constitutional threshold that states must comply with under the Supremacy Clause. ${ }^{218}$ The states are free to adopt broader procedural requirements through operation of independent state law, either as a matter of statutory, constitutional, or common law. ${ }^{219}$

Many states have indeed adopted broader standards. Some states appoint counsel to all indigents charged with criminal offenses that merely authorize imprisonment, ${ }^{220}$ and others

${ }^{218}$ See U.S. CONST. art. VI, cl. 2.

219 The states have the power to decide which criminal procedures state courts will employ, subject only to the limitations imposed by federal law under the Supremacy Clause. Although the states may not deny procedural protections guaranteed by the Fourteenth Amendment of the Constitution, they may develop procedural protections that extend beyond the requirements of the Fourteenth Amendment. See id. ("This Constitution, and the Laws of the United States which shall be made in Pursuance thereof . . . shall be the supreme Law of the Land; and the Judges in every State shall be bound thereby, any Thing in the Constitution or Laws of any State to the Contrary notwithstanding."); U.S. CONST. amend. X ("The powers not delegated to the United States by the Constitution, nor prohibited by it to the States, are reserved to the States respectively, or to the people."); U.S. CoNST. amend. XIV, § 1 ("No State shall ... deprive any person of life, liberty, or property, without due process of law . . .."); see also Shirley S. Abrahamson, Criminal Law and State Constitutions: The Emergence of State Constitutional Law, 63 TEx. L. REV, 1141, 1156-57 (1985) ("The federal constitution does not preclude the states from granting greater protections to their citizens than those granted by the federal constitution."); William J. Brennan, Jr., State Constitutions and the Protection of Individual Rights, 90 HARV. L. REV. 489, 491 (1977) ("State constitutions, too, are a font of individual liberties, their protections often extending beyond those required by the Supreme Court's interpretation of federal law."); Developments in the Law-The Interpretation of State Constitutional Rights, 95 HARV. L. REV. 1324, 1334 (1982) ("[S]tate constitutions may always be used to supplement or expand federally guaranteed constitutional rights, but may never be used to undermine or infringe them."). Furthermore, the United States Supreme Court does not have jurisdiction to review state court determinations of state law, see Murdock v. City of Memphis, 87 U.S. (20 Wall.) 590, 632-33 (1874), and even when a state court determination of state law raises a federal question, the Supreme Court will not review the case if the state court decision was also based on "adequate and independent state grounds." See Herb v. Pitcairn, 324 U.S. 117, 125-26 (1945). The "independent and adequate state ground" doctrine arises from the "case-orcontroversy" requirement of Article III; if an independent state ground for upholding the decision exists, then a reversal of the federal question will not alter the outcome and the Supreme Court adjudication would function merely as an advisory opinion, which is beyond the judicial power under Article III. See U.S. ConST. art. III, § 2; see also Preiser v. Newkirk, 422 U.S. 395, 401 (1975).

${ }^{220}$ See, e.g., Alexander v. City of Anchorage, 490 P.2d 910, 912-13 (Alaska 1971) (construing ALASKA CONST. art. $1, \S 11$ and holding that the Alaska Constitution 
prohibit the use of uncounseled convictions for sentence enhancement in subsequent prosecutions. ${ }^{221}$ Yet another group of states, however, follow the United States Supreme Court by adopting federal constitutional standards as their own state law standards. Many states appoint counsel to indigent criminal defendants only to the extent required by $S c o t t,{ }^{222}$ and several of those states have now adopted Nichols as the governing standard for collateral sentence

guarantees the right to appointed counsel in any criminal prosecution in which the offense authorizes a sentence of incarceration, loss of a valuable license, or a fine heavy enough to connote criminality); Mills v. Municipal Court, 515 P.2d 273, 282 (Cal. 1973) (stating that the California Constitution guarantees court-appointed counsel "in all felony and misdemeanor proceedings whether actual imprisonment is to follow or not") (construing CAL. CONST. art. 1, \$13); Olevsky v. District of Columbia, 548 A.2d 78, 85 (D.C. 1988) (interpreting a D.C. statute to require appointment of counsel for all offenses authorizing imprisonment); State v. Hardman, 818 P.2d 782, 784 (Idaho Ct. App. 1991) (interpreting a state statute to require appointment of counsel for offenses authorizing imprisonment of six months or more, regardless of whether such incarceration is actually imposed).

221 Many states prohibited enhancement of uncounseled misdemeanor convictions under authority of Baldasar. See, e.g., Lovell v. State, 678 S.W.2d 318, 320 (Ark. 1984); State v. Vares, 801 P.2d 555, 557-58 (Haw. 1990). Although Nichols overruled Baldasar, state courts may retain the standard by adopting the Baldasar rule under state law.

${ }^{222}$ See, e.g., CoLO. REV. STAT. § 16-5-501 (Supp. 1994) (requiring that counsel be appointed for indigent defendants charged with class two or class three misdemeanors, petty offenses, or misdemeanor traffic offenses only if the defendant will be incarcerated upon conviction); CoNN. GEN. STAT. ANN. § 51-296(a) (West 1985) (requiring that counsel be appointed for indigent defendants charged with misdemeanor offenses only if the defendant will receive a sentence of incarceration or suspended incarceration); ALA. R. CRIM. P. 6.1(a) committee cmts. (citing Scott in explaining that the right to counsel in misdemeanor cases under Rule 6.1 of the Alabama Rules of Criminal Procedure "is limited to cases in which the defendant is actually sentenced to jail"); FLA. R. CRIM. P. 3.111(b)(1) ("Counsel does not have to be provided to an indigent person in a prosecution for a misdemeanor ... if the judge, prior to trial, files in the cause a statement in writing that the defendant will not be imprisoned in the event he is convicted."); Campa v. Fleming, 656 P.2d 619, 621 (Ariz. Ct. App. 1982) (holding that the defendant had no right to counsel because the defendant was not incarcerated and noting that "there is no authority holding that Arizona has standards which are more strict in this area than the U.S. Constitution"); Duty v. State, 871 S.W.2d 400, 402 (Ark. Ct. App. 1994) (holding that indigent criminal defendants do not have a right to appointed counsel in misdemeanor prosecutions unless they are sentenced to imprisonment and citing Scott and ARK. R. CRIM. P. 8.2(b) as authority); Peoples v. State, 576 So. 2d 783, 787 (Fla. Dist. Ct. App. 1991) (stating that the Florida Constitution does not provide a broader right to counsel than the Sixth Amendment) (construing FLA. ConST. art. 1, § 16); Capelli v. State, 416 S.E.2d 136, 137 (Ga. Ct. App. 1992) (rejecting a challenge brought under both the U.S. and Georgia Constitutions that counsel is required in misdemeanor convictions that do not result in actual incarceration); State v. Apuna, 657 P.2d 1062, 1064 (Haw. Ct. App. 1983) ("We adopt the Scott rule in the construction of article I, section 14 of the Hawaii Constitution."). 
enhancement. ${ }^{223}$ For example, the West Virginia Supreme Court recently adopted Nichols as the rule for West Virginia's state constitution because the court found Nichols "persuasive." ${ }^{224}$ In Kansas, an appellate court reached a similar result ${ }^{225}$ without even mentioning state law standards; the court merely observed that Kansas courts have "traditionally ... followed the precedent established by the Supreme Court of the United States" in cases involving the right to counsel. ${ }^{226}$

State courts have also extended the reasoning of Nichols to other related areas of the law. The Supreme Court of Oregon, for example, recently held that state courts could include juvenile adjudications in calculating a defendant's criminal history under state sentencing guidelines, even though juveniles are not afforded the right to a jury trial-a right that the state constitution guarantees in all criminal prosecutions. ${ }^{227}$ The defendants relied on Baldasar as persuasive authority for the proposition that validly obtained

${ }^{223}$ Some courts decided even before Nichols that valid uncounseled misdemeanor convictions can be used in sentence-enhancement proceedings. See, e.g., Moore v. State, 352 S.E.2d 821, 822 (Ga. Ct. App. 1987) (holding that consideration of the defendant's prior uncounseled misdemeanor convictions at sentencing did not violate either the U.S. Constitution or the Georgia Constitution because the defendant had not been incarcerated for the prior convictions).

${ }^{224}$ State v. Hopkins, 453 S.E.2d 317, 324 (W. Va. 1994) (construing W. VA. CONST. art. III, $\$ 14)$.

${ }_{225}$ See Paletta v. City of Topeka, 893 P.2d 280, 286 (Kan. Ct. App. 1995) (declining to follow state court precedents based on Baldasar and adopting Nichols).

${ }^{226} \mathrm{Id}$. at 284. For other state cases citing Nichols without reference to state law, see Ghoston v. State, 645 So. 2d 936, 938-39 (Miss. 1994) (citing Nichols as "controlling" in the face of a claim that prior uncounseled convictions, for which the defendant did not receive imprisonment, should not be used to convert a fourth DUI into a felony offense); James v. Commonwealth, 446 S.E.2d 900, 904 (Va. Ct. App. 1994) (citing Nichols and Scott as authority for its holding that the prosecution must show, when introducing prior convictions at sentencing, that the defendant either had or waived counsel "in all felony cases and those misdemeanor proceedings where imprisonment resulted").

${ }_{227}$ See State v. Stewart, 892 P.2d 1013, 1017 (Or. 1995). The Oregon Constitution guarantees that "[i]n all criminal prosecutions, the accused shall have the right to public trial by an impartial jury." OR. CoNST. art. I, § 11.

For other state court decisions extending Nichols to slightly different contexts, see People v. Leary, 522 N.W.2d 630, 630 (Mich. 1994) (declaring, in an order denying appeal, that an appellate court decision prohibiting the use of uncounseled juvenile adjudications at sentencing "shall have no precedential force or effect" and citing Nichols as authority); LeGrand v. State, 527 N.W.2d 203, $211-13$ (Neb. Ct. App. 1995) (eliminating a state practice of offering defendants an opportunity to attack collaterally prior convictions sought to be used in sentence-enhancement proceedings under Boykin v. Alabama, 395 U.S. 238 (1969), after determining, partially under authority of Nichols, that the state practice was not required by the Constitution). 
adjudications are not necessarily valid for subsequent sentenceenhancement proceedings. ${ }^{228}$ The court dismissed the defendants' argument after quoting the language in Nichols explaining that recidivist statutes penalize only the last offense and that sentencing courts often consider unadjudicated conduct. ${ }^{229}$

What is disturbing about these state court decisions is that they either adopt Nichols unthinkingly and mechanically or they consciously find its reasoning "persuasive." Nichols is not a wellreasoned decision. The decision does not have to be well-reasoned to be binding on the federal judiciary, of course, but it should be well-reasoned if it is to form the basis of state constitutional or statutory standards. If the states decide to allow the use of uncounseled convictions at sentencing, they should do so because they have determined that sound reasons exist for adopting such a rule. The Supreme Court failed to produce sound reasons to support the rule, and the mere fact that the Supreme Court has exercised its power to define the Sixth Amendment standard does not provide a sound reason for foreclosing all further inquiry into the appropriate policy under state law.

\section{CONCLUSION}

The criminal procedures guaranteed by the Constitution derive their content largely from the decisions of the Supreme Court. In Gideon, the Supreme Court determined that the Sixth Amendment right to counsel embodied a right to reliable factfinding that required the federal and state governments to provide attorneys to defendants too poor to hire lawyers on their own. In Burgett and Tucker, the Court extended this guarantee against unreliable factfinding to collateral proceedings. In Scott, the Court decided that the costs of preserving reliable factfinding were not justifiable when defendants face nonimprisonment penalties for misdemeanor convictions. In Nichols, the Court decided that this class of valid but uncounseled convictions could be used collaterally to enhance prison sentences. The Court's attempt to derive this result from its Sixth Amendment precedents is unconvincing. If the decision signals a shift in opinion about the need for counsel to preserve reliable factfinding in misdemeanor prosecutions or about the appropriateness of retaining control in the Supreme Court over the

${ }^{228}$ See Stewart, 892 P.2d at 1016-17.

${ }^{229}$ See id. 
provision of defense counsel, this shift is not made explicitly. The decision thus mandates a result but provides no valid rationale to support it. For the states which administer the bulk of criminal prosecutions, Nichols is neither a decision that they must adopt nor one that provides any persuasive reason why they should adopt it. Whether criminal defendants should face enhanced penalties for previous uncounseled convictions is an issue that state courts and legislatures should arrive at independently, after full consideration of their appropriate state policies. 
. 